\title{
Magnetic resonance imaging in animal models of alzheimer's disease amyloidosis
}

\section{Review Article}

Author(s):

Ni, Ruiqing (D)

Publication date:

2021-12-01

Permanent link:

https://doi.org/10.3929/ethz-b-000517649

Rights / license:

Creative Commons Attribution 4.0 International

Originally published in:

International Journal of Molecular Sciences 22(23), https://doi.org/10.3390/ijms222312768 


\title{
Magnetic Resonance Imaging in Animal Models of Alzheimer's Disease Amyloidosis
}

\author{
Ruiqing $\mathrm{Ni}^{1,2}$
}

Citation: Ni, R. Magnetic Resonance Imaging in Animal Models of Alzheimer's Disease Amyloidosis. Int J. Mol. Sci. 2021, 22, 12768. https:// doi.org/10.3390/ijms222312768

Academic Editors: Carlo Morasso, Cristina Cereda and Stella Gagliardi

Received: 8 October 2021

Accepted: 23 November 2021

Published: 25 November 2021

Publisher's Note: MDPI stays neutral with regard to jurisdictional claims in published maps and institutional affiliations.

Copyright: (C) 2021 by the author. Licensee MDPI, Basel, Switzerland. This article is an open access article distributed under the terms and conditions of the Creative Commons Attribution (CC BY) license (https:// creativecommons.org/licenses/by/ $4.0 /)$.
1 Institute for Biomedical Engineering, ETH Zurich \& University of Zurich, 8093 Zurich, Switzerland; ni@biomed.ee.ethz.ch

2 Institute for Regenerative Medicine, University of Zurich, 8952 Zurich, Switzerland

\begin{abstract}
Amyloid-beta $(\mathrm{A} \beta)$ plays an important role in the pathogenesis of Alzheimer's disease. Aberrant $A \beta$ accumulation induces neuroinflammation, cerebrovascular alterations, and synaptic deficits, leading to cognitive impairment. Animal models recapitulating the A $\beta$ pathology, such as transgenic, knock-in mouse and rat models, have facilitated the understanding of disease mechanisms and the development of therapeutics targeting $\mathrm{A} \beta$. There is a rapid advance in high-field MRI in small animals. Versatile high-field magnetic resonance imaging (MRI) sequences, such as diffusion tensor imaging, arterial spin labeling, resting-state functional MRI, anatomical MRI, and MR spectroscopy, as well as contrast agents, have been developed for preclinical imaging in animal models. These tools have enabled high-resolution in vivo structural, functional, and molecular readouts with a whole-brain field of view. MRI has been used to visualize non-invasively the A $\beta$ deposits, synaptic deficits, regional brain atrophy, impairment in white matter integrity, functional connectivity, and cerebrovascular and glymphatic system in animal models of Alzheimer's disease amyloidosis. Many of the readouts are translational toward clinical MRI applications in patients with Alzheimer's disease. In this review, we summarize the recent advances in MRI for visualizing the pathophysiology in amyloidosis animal models. We discuss the outstanding challenges in brain imaging using MRI in small animals and propose future outlook in visualizing $A \beta$-related alterations in the brains of animal models.
\end{abstract}

Keywords: Alzheimer's disease; amyloid- $\beta$; animal model; diffusion tensor imaging; functional imaging; magnetic resonance imaging; magnetic resonance spectroscopy

\section{Introduction}

The two core pathological hallmarks of Alzheimer's disease (AD) are extracellular amyloid-beta $(\mathrm{A} \beta)$ plaques and intracellular neurofibrillary tangles, resulting from the abnormal accumulation of misfolded $A \beta$ and tau [1]. $A \beta$ plays a central role in the pathogenesis of $\mathrm{AD}$ and downstream pathophysiological events [2]. The pathophysiological changes in AD start many years before the onset of clinical symptoms [3]. Recent advances in diagnostic imaging have provided insights into the time course of AD pathology, including $A \beta$, tau, and neuroinflammation, in patients and in animal disease models [4,5]. Magnetic resonance imaging (MRI) is widely used both in clinical settings for assisting in the diagnosis toward precision medicine and in preclinical research in small-animal models. Structural MRI for assessing the neurodegeneration (brain atrophy) in the ATN framework has offered a valuable tool for early and differential diagnosis of AD and for disease staging [4,6]. Moreover, multiplex MRI sequences, such as diffusion tensor imaging (DTI) for white matter integrity assessment, resting-state (rs) functional MRI for functional connectivity analysis [7,8], as well as arterial spin labeling (ASL) for cerebral perfusion measurement, have emerged as potential diagnostic biomarkers for AD.

Several generations of animal models of AD amyloidosis have been developed. The animal models, including transgenic APPswe, APP/PS1, APP23, and J20 mouse models; 
McGill-R-Thy1-APP rat models [9-13]; and $2^{\text {nd }}$ generation App ${ }^{\text {NL-G-F }}$ and App ${ }^{\text {hu/hu }}$ knockin and $3^{\text {rd }}$-generation mouse models, overexpress human Amyloid Precursor Protein (APP) and/or Presenilin (PS) [14-17]. The A $\beta$ deposits, both parenchymal plaques and cerebral amyloid angiopathy (CAA), first accumulate in the neocortex, limbic regions and later in the subcortical brain regions. The speed of pathology development in these animal models depends on APP expression levels and mutations. A $\beta$ pathology, especially the most neurotoxic oligomeric $A \beta$, plays a crucial role in the disease pathogenesis in animal models and leads to downstream gliosis, neuronal loss, and functional and cognitive impairment $[18,19]$. In addition, models harboring both $A \beta$ and tau pathology, such as $5 \times$ FAD and $3 \times \mathrm{Tg}$ mice and TgF344 rats, have been commonly used [20-22]. In this review, we summarize recent advances in MRI, contrast agents, and MR spectroscopy in probing the alterations in brains of $\mathrm{AD}$ amyloidosis animal models. We outline the outstanding challenges and provide an outlook for further development of preclinical MR in animal models of $\mathrm{AD}$ amyloidosis.

\section{A $\beta$ Imaging}

In vivo $A \beta$ detection and longitudinal monitoring in mouse models of $A D$ amyloidosis have provided insights into the disease mechanisms and treatment effects. MRI detection of $\mathrm{A} \beta$ deposits has also been developed with or without using contrast agents (Table 1 ). A $\beta$ imaging using MRI without contrast agents has been developed by exploring the changes in tissue proton MR properties, such as $\mathrm{T}_{2}, \mathrm{~T}_{2}{ }^{*}[23,24]$ (Figure 1e), magnetic susceptibility, magnetization transfer imaging $[25,26]$, and chemical exchange-sensitive spin-lock (CESL) imaging [27]. The $T_{2}$ relaxation time was found to be associated with $A \beta$ pathology in several amyloidosis mouse models [28-30]. As iron, copper, and zinc accumulate inside the $\mathrm{A} \beta$ plaques [31], susceptibility-weighted imaging (SWI) and quantitative susceptibility mapping (QSM) have been used to detect $\mathrm{A} \beta$ aggregates and iron accumulation in brains of APP/PS1 and Tg-SwDI mice [32,33]. A few exogenous MRI contrast agents that can specifically bind to $\mathrm{A} \beta$ have been developed, including the following:

(1) Gadolinium (Gd) based: Gd-diethylenetriamine pentaacetate (DTPA)-A $\beta 1-40$, Gd-DTPA-K6A $31-30$, cyanine-conjugated Gd (III) complex, Gd-pF(ab')24, and liposomal macrocyclic Gd-ADx-001 [34-39] (Figure 1f).

(2) Superparamagnetic iron oxide (SPIO) based: APP-SiMag, ultrasmall SPIO-polyethylene glycol-A $\beta 1-42 . B$, and IgG4.1 NP bifunctional ultrasmall SPIO [40-44]. Dudeffant et al. demonstrated the detection of compact $\mathrm{A} \beta$ plaques as well as $\mathrm{CAA}$ and microhemorrhages in five mouse lines $\left(\mathrm{APP}_{\mathrm{SL}} / \mathrm{PS}_{\mathrm{M} 146 \mathrm{~L}}, \mathrm{APP} / \mathrm{PS}_{\mathrm{dEg}}, \mathrm{APP} 23, \mathrm{APP}_{\mathrm{SwDI}}\right.$, and $3 \times \mathrm{Tg}$ ) and in AD human brains using DOTAREM ${ }^{\circledR}($ Gd-DOTA) at 7 T MRI even around a diameter of $25 \mu \mathrm{m}$ [45].

(3) Manganese (Mn) based: Mn-oxide-nanoparticle-conjugated HMON-A $\beta 40$ [28], Mn chloride [46], monocrystalline iron oxide nanoparticles [35], and sialic-acid-coated bovine serum albumin magnetic nanoparticle [47], have been reported for $\mathrm{A} \beta$ deposit detection.

(4) ${ }^{19} \mathrm{~F}$ and ${ }^{1} \mathrm{H}$ MRI using contrast agents such as small chemical dyes FSB, TFMB, bovine serum albumin@FDQDs, Shiga-Y5, and Shiga-Y51 have also been reported for in vivo $A \beta$ imaging in animal models [37,48-52].

Moreover, several contrast agents specific to $\mathrm{A} \beta$ oligomer (antibody-based or chemical probe) have been reported. Viola et al. reported using 12-16 $\mathrm{nm} \mathrm{Fe} \mathrm{O}_{4}$ magnetic nanostructures (MNS) conjugated with A $\beta$-oligomer-specific antibody NU4 for detecting $A \beta$ oligomers in mouse brains [53]. Rozema et al. reported $A \beta$-oligomer-specific antibody-based ACU193-MNS for detecting the $A \beta$ oligomer levels in rabbits by using MRI [54]. As the size of the antibody hinders the permeability of its blood-brain barrier (BBB), one strategy to facilitate the antibody delivery is to link a fraction of the antibody with a transferrin [55] or scavenger receptor. Liu et al. demonstrated in vivo detection in APP/PS1 mice by using W20/XD4-SPIO nanoparticles conjugated with an A $\beta$-oligomerspecific single-chain variable fragment ( $\mathrm{scFv}$ ) and a scavenger receptor [56] (Figure 1g-h). Chen et al. and Dong et al. reported curcumin-derivative-conjugated magnetic nanoparti- 
cles (Cur-MNPs) for in vivo imaging of $A \beta$ with high contrast in APPswe and $5 \times$ FAD mice $[57,58]$.

Table 1. MRI for detecting cerebral $\mathrm{A} \beta$ deposits in animal models of amyloidosis.

\begin{tabular}{|c|c|c|}
\hline MRI Using Endogenous Contrast & Animal & References \\
\hline$T_{2}$, relaxation time & $5 \times$ FAD, APP, APP/PS1, APPswe, PS mice & {$[29,30,59-62]$} \\
\hline 3D GRE, $\mathrm{T}_{2}^{*} 16.4 \mathrm{~T}$ & APP23 mice & [24] \\
\hline $\mathrm{T}_{2}{ }^{*} \mathrm{~W} \mathrm{GE}, \mathrm{T}_{2} \mathrm{~W} \mathrm{SE}$ & $\mathrm{APP} / \mathrm{PS1}, \mathrm{APP}_{\mathrm{V} 717 \mathrm{I}}$ mice & {$[23,39,63,64]$} \\
\hline CESL & APP/PS1 mice & [27] \\
\hline $\mathrm{T}_{1} \mathrm{w}, \mathrm{CE}-\mathrm{MR}$ & APP/PS1, PDAPP mice & [65] \\
\hline $3 \mathrm{D} \mathrm{GE} \mathrm{T}{ }^{*} \mathrm{~W}$ & APP/PS1, PS1 mice & [66] \\
\hline MTC & $\mathrm{APP} / \mathrm{PS} 1$ mice & {$[25,26]$} \\
\hline CRAZED, GE & $\mathrm{APP}_{\mathrm{V} 717 \mathrm{I}} \times \mathrm{ADAM} 10-\mathrm{dn}$ mice & [67] \\
\hline QSM, SWI & Tg-SwDI, APP/PS1 mice & {$[32,33]$} \\
\hline MRI with Contrast Agents & Animal & References \\
\hline${ }^{19} \mathrm{~F}, \mathrm{BSA} @ \mathrm{FGQDs}$ & AD mice & [49] \\
\hline${ }^{19} \mathrm{~F}, \mathrm{TFMB}$ & APP mice & [50] \\
\hline${ }^{19} \mathrm{~F}_{1}^{1}{ }^{1} \mathrm{H}, \mathrm{FSB}$ & APPswe mice & [48] \\
\hline${ }^{19} \mathrm{~F}$, Shiga-Y51 & APP/PS1 mice & [51] \\
\hline${ }^{19} \mathrm{~F}$, FMeC1 (Shiga-Y5) & APPswe mice & [52] \\
\hline $\mathrm{T}_{2}{ }^{*} \mathrm{~W}$, sialic-acid-coated BSA MNP & APP/PS1 mice & [47] \\
\hline $\mathrm{T}_{2}{ }^{*}, \mathrm{Gd}-\mathrm{DTPA}-\mathrm{K} 6 \mathrm{~A} \beta 1-30$ & APP/PS1, APPswe mice & [36] \\
\hline $\mathrm{T}_{1} \mathrm{w}$, cyanine-Gd(III) complex & $5 \times$ FAD mice & [37] \\
\hline $\mathrm{T}_{2}{ }^{*} \mathrm{~W}$ GE Gd, Gd-DOTA, DOTAREM ${ }^{\circledR}$, & $\mathrm{APP}_{\mathrm{SL}} / \mathrm{PS}_{\mathrm{M} 146 \mathrm{~L}}, \mathrm{APP} / \mathrm{PS}_{\mathrm{dE}}, \mathrm{APP} 23, \mathrm{APP}_{\mathrm{SwDI}}, 3 \times \mathrm{Tg}, \mathrm{PS} 1$ mice & {$[34,45]$} \\
\hline $\mathrm{T}_{2}{ }^{*} \mathrm{w}$ GE, $\mathrm{T}_{2} \mathrm{w}$ SE, Gd-pF(ab')24.1 & APP/PS1 mice & [39] \\
\hline $\mathrm{T}_{2}{ }^{*} \mathrm{~W}$, Gd-DTPA-A $\beta 1-40$, MION & APP/PS1 mice & [35] \\
\hline SWI MGE RARE, APP-SiMag & $3 \times$ Tg mice & [41] \\
\hline $\mathrm{T}_{2}{ }^{*} \mathrm{~W}$, USPIO-PEG-A $\beta 1-42 . \mathrm{B}$ & APP/PS1 mice & [40] \\
\hline $\mathrm{T}_{1} \mathrm{w} \mathrm{SE}, \mathrm{ADx}-001$ & APP/PS1 mice & [38] \\
\hline $\mathrm{T}_{2}{ }^{*} \mathrm{~W}$, anti-A $\beta$ PP SPIONs & APP/PS1 mice & [42] \\
\hline $\mathrm{T}_{2}{ }^{*} \mathrm{w}, \mathrm{IgG} 4.1 \mathrm{NP}$ & APPswe mice & [44] \\
\hline $\mathrm{T}_{2}^{*} \mathrm{w}$ GE, SPIO & APP23, APP23 $\times$ PS45 mice & [43] \\
\hline $\mathrm{T}_{1} \mathrm{w}, \mathrm{HMON}-\mathrm{A} \beta 40$ & APP/PS1 mice & [28] \\
\hline $\mathrm{T}_{2}{ }^{*} \mathrm{~W}$ MGE, $\mathrm{MnCl}_{2}$ & $5 \times$ FAD mice, TgF344 rats & [46] \\
\hline $\mathrm{T}_{2}{ }^{*} \mathrm{~W}$, Cur-MNPs & $5 \times$ FAD, APPswe mice & {$[57,58]$} \\
\hline $\mathrm{T}_{2}{ }^{*} \mathrm{~W}, \mathrm{~W} 20 / \mathrm{XD} 4-\mathrm{SPIONs}$ & APP/PS1 mice & [56] \\
\hline $\mathrm{T}_{2}{ }^{*} \mathrm{~W}$, NU4MNS A $\beta$ oligomer & $5 \times$ FAD mice & [53] \\
\hline
\end{tabular}

BSA, bovine serum albumin; CE, contrast enhanced; CESL, chemical-exchange-sensitive spin-lock; CRAZED, COSY revamped with asymmetric z-GRE detection; Gd, gadolinium; GE, gradient echo; GRE, gradient recalled echo; MGE, multi-echo GRE; MION, monocrystalline iron oxide nanoparticles; MnCl2, Manganese(II) chloride; MNP, magnetic nanoparticle; MNS, magnetic nanostructures; MTC, magnetization transfer contrast imaging; NP, nanoparticle; PEG, polyethylene glycol; QSM, quantitative susceptibility mapping; RARE, rapid acquisition with relaxation enhancement; SE, spin echo; SWI, susceptibility-weighted imaging; USPION, ultrasmall superparamagnetic iron oxide nanoparticles; w, weighted.

\section{Functional Imaging}

Synaptic impairment, aberrant excitatory neuronal activity, gamma oscillations, and disrupted circuit are early features in amyloidosis animal models [68-71]. Clusters of hyperactive neurons are observed in the vicinity of A $\beta$ plaques in APP mouse models [72]. There is a vicious cycle of $A \beta$-dependent neuronal hyperactivation initiated by the suppression of glutamate reuptake [73]. Neurovascular uncoupling and impaired cerebral blood flow (CBF) have been demonstrated by MRI and optical imaging modalities [74]. 


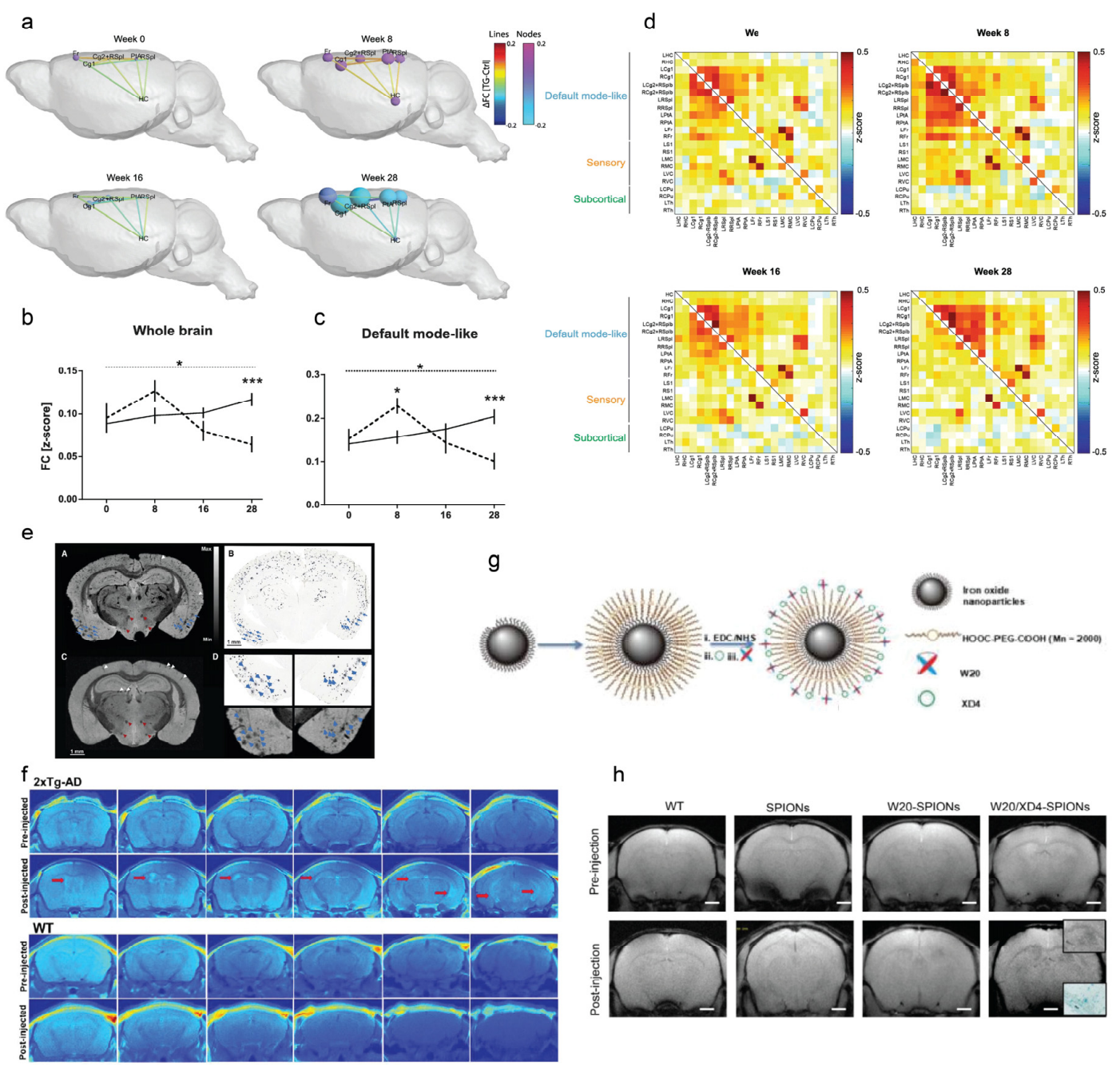

Figure 1. Functional MRI and amyloid imaging in amyloidosis animal models. (a-d) Aberrant functional connectivity (FC) in the default mode-like network (DMN) in the Tet-Off APP mice with doxycycline treatment. (a) difference in FC within (nodes) and between (lines) regions in the DMN over time: weeks $0,8,16$, and 24 . The inter-node FC difference is represented by the lines, with the color scale illustrating the actual FC difference between Tet-Off APP and Ctrl, with orange indicating a stronger connection in the TG mice. The intra-node size represents the difference in the average FC of a specific region from all other regions inside DMN. (c) ROI-based FC analysis. FC matrices show the average z-transformed functional connectivity (zFC) for Ctrl (supra-diagonal) and TG (sub-diagonal) animals at weeks 0, 8, 16, and 28 post doxycycline treatment. Each square indicates the zFC between a pair of ROIs. The color scale represents the connectivity strength, with white indicating a low zFC and red/blue indicating positive/negative zFC values. (d) Average FC within each network, the mean FC (z-score) over time for both groups in the whole brain, and the default-mode-like network; the dashed line corresponds to the TG group and the full line to the Ctrl group. ${ }^{*} p<0.05 ; * * *<0.001$. Reproduced from [75] with permission from Springer Nature. (e) MRI amyloid imaging. (A) $\mathrm{T}_{2}{ }^{*}$-weighted image at $16.4 \mathrm{~T}$ of a 30-month-old transgenic APP23 mouse and (B) corresponding amyloid histology; (C) $\mathrm{T}_{2}{ }^{*}$-weighted image at $16.4 \mathrm{~T}$ of the control mouse. Mammillothalamic tract and perifornical nucleus (red arrowheads). (D) Higher magnification of A and B of single amyloid plaques (blue arrowheads). Reproduced from [24] with permission from Society of Nuclear Medicine and Molecular Imaging. (f) In vivo $\mathrm{T}_{1}$-weighted MR-pseudocolor-mapped images of 6-month-old double Tg-AD and age-matched wild-type mice before and after i.v. injection of the cyanine-Gd(III) complex at different depths in which the images were taken $10 \mu \mathrm{m}$ apart $90 \mathrm{~min}$ post-injection of the probe on a 7.0 T MR scanner. Reproduced from [37] with permission from American Chemical Society. (g,h) W20/XD4-SPIONs characterization (g). The carboxyl of PEG on the paramagnetic iron oxide nanoparticles (SPIONs) was activated with EDC and NHS. SR-A activator XD4 and oligomer-specific ScFv antibody W20 were conjugated to the nanoparticles. (h) In vivo $\mathrm{T}_{2}{ }^{*}$-weighted images of the probe distribution in AD mouse brains after intravenous injection of W20/XD4-SPIONs, W20-SPIONs, and SPIONs. Boxed regions are shown at a higher magnification or stained by Prussian blue. Scale bar, $1 \mathrm{~mm}$. Reproduced from [56] with permission from Dovepress. 


\subsection{Manganese-Enhanced (ME) MRI}

Both the neuronal tracing MEMRI and the activity-induced MEMRI methods for detecting active neural regions during a task or a stimulation, independent of hemodynamics, have been developed [76,77]. MEMRI is based on the following properties of manganese ions $\left(\mathrm{Mn}^{2+}\right): \mathrm{Mn}^{2+}$ is a paramagnetic ion that shortens the $\mathrm{T}_{1}$ relaxation time, and is an excellent $\mathrm{T}_{1}$ contrast agent; as a calcium ion $\left(\mathrm{Ca}^{2+}\right)$ analog, $\mathrm{Mn}^{2+}$ can enter via voltagegated $\mathrm{Ca}^{2+}$ channels inside neurons; and $\mathrm{Mn}^{2+}$ can cross synapses to neighboring neurons and along axon via microtubule-dependent axonal transport [76,77]. Activity-induced MEMRI has been applied in APPswe, APP $\times$ PS1-Ki, CVN-AD, J20, and $5 \times$ FAD mice and TgF344 rats [46,78-81] (Table 2). Most MEMRI studies found hyperactivation and functional abnormalities in the APP animal models. However, studies have also reported that activity-induced MEMRI cannot detect hyperactivation in the APP $\times$ PS1-Ki mouse [78].

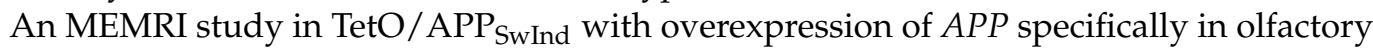
neurons was shown to detect laminar changes and neurodegeneration in the olfactory bulb [82]. Neuronal tracing studies with MEMRI by direct injection of manganese chloride solution into the mouse brain region enable the detection of impaired axon transport. Intranasal administration of $\mathrm{Mn}$ showed decreased axonal transport rates in the olfactory system prior to $\mathrm{A} \beta$ plaque formation in a mouse model in APPswe and $3 \times \mathrm{Tg}$ mice [83-85] and in the hippocampus-basal forebrain pathway in $\mathrm{TetO} / \mathrm{APP}_{\text {SwInd }}$ mice [86].

\subsection{Resting-State Functional MRI}

fMRI has enabled a better understanding of brain activity and has become a workhorse in neuroimaging [7] and a potential early biomarker for neurodegenerative diseases. Bloodoxygen-level-dependent (BOLD) signals from rs-fMRI have been widely used as a readout for brain function [87]. Early hypersynchrony of BOLD resting-state networks in the telencephalic, interhemispheric, and hippocampal regions, as well as the fornix, has been reported in amyloidosis mouse models, providing a predictive value for later cognitive dysfunction [81,88-95] (Table 2). Latif-Hernandez et al. reported that subtle behavioral changes and increased prefrontal-hippocampal network synchronicity in APP ${ }^{\mathrm{NL}-\mathrm{G}-\mathrm{F}}$ mice occur prior to the $A \beta$ plaque deposition [96]. Ben-Nejma et al. reported that an increased level of soluble $A \beta$ causes early aberrant brain network hyper-synchronization in the default mode network (DMN)-like brain regions in inducible transgenic Tet-Off APP animal model at 8 weeks post doxycycline treatment; hypo-synchronization was detected by rs-fMRI at 20 weeks post doxycycline treatment in mature-onset Tet-Off APP mice [75] (Figure 1a-d). Another study reported diminished functional connectivity in APP/PS1 mice compared to wild-type littermates [97]. Canter et al. demonstrated that the DMN is affected early, at 4 months-of-age prior to the limbic system, along with a networkspecific amyloid progression in $5 \times$ FAD mice harboring both $A \beta$ and tau pathologies [98]. Tudela et al. reported an early alteration in the anterior DMN subnetwork in TgF344 rats compared to wild-type rats by rs-fMRI using independent component analysis [99].

\subsection{Arterial Spin Labelling (ASL)}

ASL is used to quantify tissue blood flow or perfusion and is also routinely performed in the clinical setting [100]. Cortical hypoperfusion by using ASL has been reported in APP/PS1, Tg-SwDI, arcA $\beta$, APPswe, and APP23 mice [24,101-109], as well as in $3 \times \mathrm{Tg}$, bigenic, and $5 \times$ FAD mice harboring both $A \beta$ and tauopathy (Table 2; Figure 1f). Reduced cortical CBF was observed in the aged arcA $\beta$ mice (24 months-of-age) compared to aged wild-type mice and young arcA $\beta$ mice (Figure 2i,j). Cruz Hernández et al. demonstrated that neutrophil adhesion in brain capillaries impairs the CBF and that treatment using anti-neutrophil marker antibody reverses the CBF reduction and memory impairment in APP/PS1 mice [101]. 
Table 2. MRI for functional and neurochemical changes in animal models of amyloidosis.

\begin{tabular}{|c|c|c|c|}
\hline Target & MRI & Animal & References \\
\hline BOLD & rs-fMRI & $\begin{array}{c}\text { APP }{ }^{N L-F / N L-F ~ k i ~ m i c e ~} \\
\text { APP } / \text { PS1 mice } \\
\text { arcA } \beta \text { mice } \\
\text { TgCRND8 mice } \\
\text { TgF344-AD rats } \\
\text { PDAPP mice } \\
\text { APPswe mice } \\
\text { McGill-R-Thy1-APP rats } \\
3 \times \text { Tg mice } \\
\text { E22 } \triangle \mathrm{A} \beta \text { mice } \\
\text { TetO-APPswe/ind mice }\end{array}$ & $\begin{array}{c}{[90,96]} \\
{[92,93,97,110,111]} \\
{[88,92,112]} \\
{[113]} \\
{[99,114]} \\
{[89]} \\
{[89,115]} \\
{[116]} \\
{[91]} \\
{[92]} \\
{[75]}\end{array}$ \\
\hline $\mathrm{CBF}$ & ASL & $\begin{array}{c}\text { Bigenic mice } \\
\text { arcA } \beta \text { mice } \\
3 \times \text { Tg mice } \\
\text { APP DSL ki mice } \\
\text { APP23 mice } \\
\text { APP } / \text { PS1 mice } \\
\text { J20 mice } \\
\text { Tg-SwDI mice } \\
\text { PS2APP mice } \\
5 \times \text { FAD mice } \\
\text { TetOAPPswe, CAA mice } \\
\text { APPswe mice }\end{array}$ & $\begin{array}{c}{[117]} \\
{[104,105]} \\
{[118]} \\
{[119]} \\
{[24,120]} \\
{[101,102,111,120-125]} \\
{[106]} \\
{[126,127]} \\
{[108]} \\
{[128,129]} \\
{[130]} \\
{[107,131]}\end{array}$ \\
\hline CBV & fMRI & $\begin{array}{l}\text { BiAT mice } \\
\text { APP23 mice } \\
\text { arcA } \beta \text { mice } \\
\text { PDAPP mice } \\
\text { APP/PS1 mice } \\
\text { APPswe mice } \\
\text { J20 mice }\end{array}$ & $\begin{array}{c}117,132] \\
{[43,133-136]} \\
{[104,137]} \\
{[138]} \\
{[111,124]} \\
{[110]} \\
{[139]}\end{array}$ \\
\hline Synaptic funtion & MEMRI & $\begin{array}{c}3 \times \text { Tg mice } \\
\text { APP } / \text { PS1-Ki mice } \\
\text { J20 mice } \\
\text { APPswe mice } \\
5 \times \text { FAD mice } \\
\text { CVN-AD mice } \\
\text { TgF344 rats }\end{array}$ & $\begin{array}{c}{[85]} \\
{[78]} \\
{[79]} \\
{[26,83,84,107]} \\
{[46,80]} \\
{[81]} \\
{[46]}\end{array}$ \\
\hline $\mathrm{CMRO}_{2}$ & ${ }^{17} \mathrm{OZTE}$ & APPPS1 mice & [140] \\
\hline BBB integrity & DCE & $5 \times$ FAD, APOE mice & [141] \\
\hline & DGE & $\begin{array}{c}\text { APP/PS1 mice } \\
\text { APP23 mice } \\
\text { APP } / \text { PS1 mice } \\
5 \times \text { FAD mice }\end{array}$ & $\begin{array}{c}{[142]} \\
{[143]} \\
{[144,145]} \\
{[129]}\end{array}$ \\
\hline Neurochemical profiles & ${ }^{1} \mathrm{H}$ MRS & $\begin{array}{c}\text { TgF344 rats } \\
\text { APP } / \text { PS1 mice } \\
5 \times \text { FAD mice } \\
3 \times \text { Tg mice } \\
\text { APPswe mice } \\
\text { TASTPM, APP } / \text { PS2 } / \text { Tau mice }\end{array}$ & $\begin{array}{c}{[146]} \\
{[121,147-151]} \\
{[152]} \\
{[153]} \\
{[115,154]} \\
{[155]}\end{array}$ \\
\hline
\end{tabular}

ASL, arterial spin labeling; BBB, blood-brain barrier; BOLD, blood-oxygen-level dependent; CBF, cerebral blood flow; CBV, cerebral blood volume; $\mathrm{CE}$, contrast enhanced; $\mathrm{CEST}$, chemical exchange saturation transfer; $\mathrm{CMRO}_{2}$, cerebral metabolic rate of oxygen consumption; $\mathrm{DCE}$, dynamic contrast enhanced; DGE, dynamic glucose enhanced; fMRI, functional magnetic resonance imaging; MEMRI, manganese-enhanced magnetic resonance imaging; MRS, magnetic resonance spectroscopy; ZTE, zero echo time. 

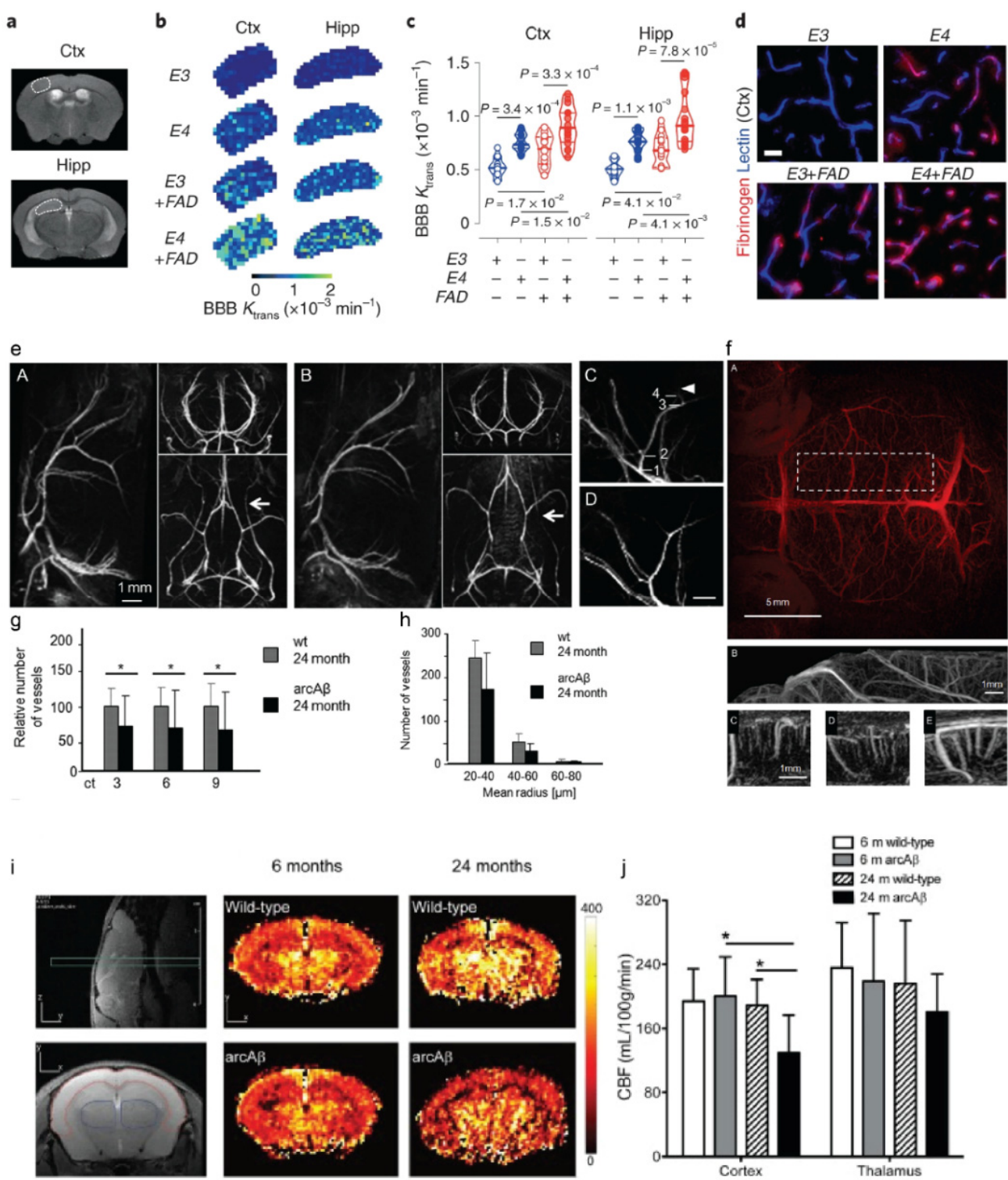

6 months
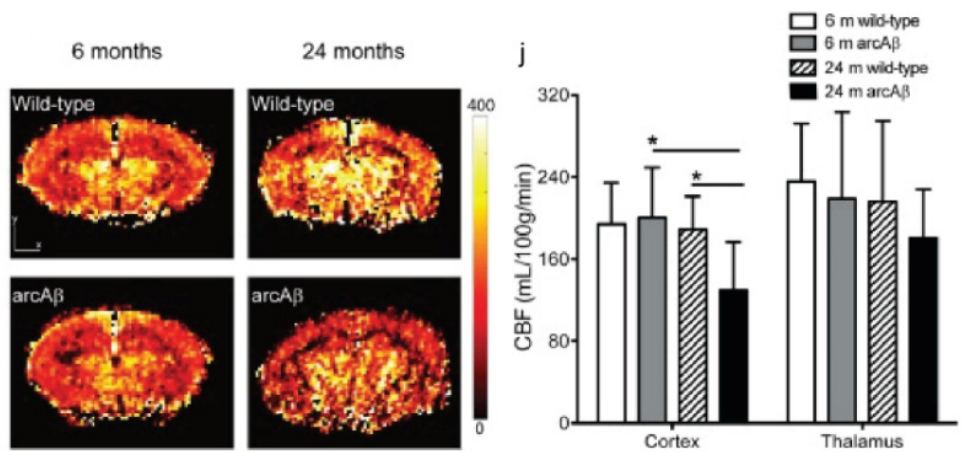

Figure 2. MRI of blood-brain-barrier permeability and cerebrovasculature in amyloidosis animal models. (a-d) $\mathrm{T}_{2}$-weighted scans displaying regions of interest: primary somatosensory cortex (Ctx) and hippocampus (Hipp). Representative $\mathrm{K}^{\text {trans }}$ maps (b) and values (c) in the Ctx and Hipp in APOE3 (E3, hollow blue circles), APOE4 (E4, solid blue circles), APOE3; $5 \times$ FAD (E3 + FAD, hollow red circles), and APOE4; $5 \times$ FAD (E4 + FAD, solid red circles) mice generated from dynamic contrast-enhanced MRI scans. (d) Fibrinogen+ perivascular capillary deposits (red) in the Ctx. Blue, lectin+ endothelial profiles; scale bar, $20 \mu \mathrm{m}$. Reproduced with permission from [141] from Springer Nature. (e-h) High-resolution magnetic resonance angiography (MRA). (e) Time-of-flight-MRA intra- and extracranial vasculature of 24-month-old wild-type and $\operatorname{arcA} \beta$ mice $(\mathrm{A}, \mathrm{B})$ in sagittal, axial, and horizontal views. Flow voids are seen in extracranial vessels (white arrows). Sections of maximum intensity projections (MIPs) of the anterior cerebral artery of a 4- and a 24-month-old (C,D) wild-type control mouse. Scale bar, $1 \mathrm{~mm}$. (f) Contrast-enhanced MRA; MIPs derived from a 3D stack of difference images viewed in horizontal (A), sagittal (B-D), and axial (E) orientations. (g,h) Semiautomated analysis of intracortical vessel density. (g) Significant decrease in the number of vessels was observed in a 24-month-old arcA $\beta$ mouse compared with a wild-type mouse corresponding to 3,6 , and 9 pixels, ( ${ }^{*} p<0.05$, repeated-measures ANOVA, and Tukey's test). (h) Number of vessels categorized according to their estimated vessel radius when the connectivity threshold was set to 3 . Reproduced with permission from [156] from Society of Neuroscience. $(\mathbf{i}, \mathbf{j})$ Regional hypoperfusion in aged arcA $\beta$ mice assessed by arterial spin labeling MRI. Anatomical position of perfusion MRI and $\mathrm{T}_{2}$-weighted scan in the sagittal view. Representative coronal cerebral blood flow (CBF) map of 6- and 24-month-old wild-type littermate; $(j)$ reduced CBF in the cortex of a 24-month-old $\operatorname{arcA} \beta$ mouse compared to an age-matched wild-type mouse and a 6-month-old arcA $\beta$ mouse; * $p<0.05$, one-way ANOVA with post hoc correction. Reproduced from [105] with permission from Elsevier. 


\subsection{Cerebrovascular Reactivity Measurement}

Vasodilatory-stimulus-challenged fMRI assesses the cerebrovascular reactivity based on the cerebral hemodynamic changes and reflects the vascular reserve and autoregulatory function [157]. Different vasodilatory stimuli, including carbon dioxide, breath-hold task (in humans), and acetazolamide, have been used in animal models [133,137]. In addition, impaired cerebrovascular reactivity assessed by using fMRI with carbon dioxide as the stimulus has been reported in patients with mild cognitive impairment and AD [157-159]. In an amyloidosis mouse model, Gd- or SPIO-based contrast agents (e.g., Endorem) were intravenously injected through a tail vein to monitor the signal alterations due to the administration of acetazolamide [137]. Reduced cerebrovascular reactivity has been reported in APP/PS1, arcA $\beta$, APPswe, APP23, J20, PDAPP, and BiAT mice compared to the wild-type mice $[43,104,111,117,136]$ (Table 2$)$.

\section{Neurochemical Changes Detection}

\subsection{Magnetic Resonance Spectroscopy (MRS)}

MRS has been shown to detect the distinct metabolic profiles in APP/PS1 [121,147-151], and APPswe mice $[115,154]$ compared to wild-type mice. Several studies have reported a reduced N-acetylaspartate/creatine ratio $[148,149]$ and a lower glutamate level in APP/PS1 mice compared to wild-type mice [121]. Different metabolic profiles have also been demonstrated in animal models harboring both $\mathrm{A} \beta$ and tau pathologies, including $3 \times \mathrm{Tg}$ mice [153], $5 \times$ FAD mice [152], APP/PS2/Tau mice [155], and TgF344 rats [146] (Table 2). Lee et al. demonstrated a 35\% decrease in the availability of metabotropic glutamate receptor 5 measured by PET; a decrease in the levels of glutamate, $\mathrm{N}$-acetylaspartate, and taurine; and an increase in the level of lactate by ${ }^{1} \mathrm{H}$ MRS in $5 \times$ FAD mice compared to wild-type at 5 months-of-age [152]. Using longitudinal ${ }^{1} \mathrm{H}$ MRS, Chiquita et al. showed an early loss of taurine in the hippocampus in $3 \times \mathrm{Tg}$ mice compared to wild-type mice [153]. Micotti et al. reported striatal atrophy and increases in the level of myo-inositol in TASTPM and APP/PS2/Tau mice compared to wild-type mice, respectively [155].

\subsection{Chemical Exchange Saturation Transfer (CEST)}

Molecular MR imaging based on CEST offers improved sensitivity and can detect changes in the levels of glucose, glutamate, creatine, and myoinositol. Endogenous CEST measurements have been reported in amyloidosis models: Glucose CEST MRI detects unlabeled endogenous glucose at physiologically relevant concentrations using proton-only MRI scanners (Table 2). Using glucose CEST MRI, Tolomeo et al. demonstrated a reduced cerebral 2-deoxy-D-glucose uptake in APP23 mice compared to wild-type mice [143]. Igarashi et al. demonstrated a reduced level of glutamate measured by using glutamate CEST, as an indicator of synaptic dysfunction, in the parietal cortex but not in the hippocampus of $5 \times$ FAD mice compared to wild-type mice [129]. Using creatine CEST MRI, Chen et al. demonstrated a reduced level of creatine in the cortex and corpus callosum of APP/PS1 mice compared to wild-type mice at 6 months-of-age [145]. Chen et al. showed a reduced saturation transfer difference for the composite protein amide proton in APP/PS1 mice compared to the age-matched wild-type mice [144].

\section{Cerebrovascular Imaging}

Accumulating evidence indicates the vascular contribution to cognitive impairment and in the development of AD [160,161]. Impaired cerebral vasculature has also been reported in various amyloidosis amyloid models with parenchymal $A \beta$ plaques and different levels of CAA [162,163].

\subsection{Susceptibility Weighted Imaging (SWI)}

The presence of iron can be detected by MRI due to its effect on the surrounding tissue, giving rise to detectable changes in transverse $T_{2}$ relaxation by using $T_{2}{ }^{*}$ and in susceptibility by using SWI and QSM (Table 3). A previous X-ray microscopy study 
reported the presence of particulate and crystalline iron inside the dense $A \beta$ plaque core in the APP/PS1 mouse brain [164]. Beckmann et al. showed microhemorrhages in $\beta$-secretase inhibitor-treated APP23 mice by using $\mathrm{T}_{2}{ }^{*}$-weighted imaging [165]. A recent study by Maniskas et al. demonstrated a gender difference in the number of cerebral microbleeds by using a $\mathrm{T}_{2}{ }^{*}$ sequence in Tg-SwDI mice (with a higher load of microbleeds in female mice) [166]. SWI and QSM have been performed in $\operatorname{arcA} \beta, A P P / P S 1$, and CVN-AD mice at $9.4 \mathrm{~T}$ [81,112,167-169]. McIntosh et al. showed that iron accumulation detected by SWI contributes to the altered cerebral metabolism and cognitive impairment in APP/PS1 mice [168].

Table 3. MRI for detecting atrophy, white matter integrity, and cerebral vasculature alterations in animal models of amyloidosis.

\begin{tabular}{|c|c|c|c|}
\hline & MRI & Animal & References \\
\hline Atrophy & $\mathrm{T}_{2}$ & $\begin{array}{c}\text { APP/J20 mice } \\
\text { APP/PS2/Tau mice } \\
\text { TASTPM mice } \\
\text { APP/PS1 mice } \\
\text { McGill-R-Thy1-APP rats } \\
\text { PDAPP mice } \\
\text { APP-Au mice } \\
3 \times \text { Tg mice } \\
\text { APPswe mice } \\
\text { APP/PS1KI mice } \\
\text { APP/TTA mice }\end{array}$ & $\begin{array}{c}{[170]} \\
{[155]} \\
{[155,171]} \\
{[102,122,149,172,173]} \\
{[174]} \\
{[175,176]} \\
{[177]} \\
{[91,178,179]} \\
{[131]} \\
{[180]} \\
{[181]}\end{array}$ \\
\hline & DKI & $\begin{array}{l}\text { APP / PS1 mice } \\
3 \times \text { Tg mice }\end{array}$ & $\begin{array}{l}{[182]} \\
{[183]}\end{array}$ \\
\hline & qMTI & APPswe mice & {$[184]$} \\
\hline White matter integrity & DTI & $\begin{array}{c}\text { TgF344 rats } \\
\text { APPswe mice } \\
\text { PDAPP mice } \\
\text { App NL-G-F knock-in mice } \\
\text { APP /PS1 mice } \\
\text { APP23 mice } \\
3 \times \text { Tg mice } \\
\text { TgCRND8 mice } \\
\text { APP/TTA mice } \\
\text { CVN-AD mice } \\
5 \times \text { FAD mice }\end{array}$ & $\begin{array}{c}{[185]} \\
{[184,186-188]} \\
{[189]} \\
{[71]} \\
{[121,190-194]} \\
{[195]} \\
{[91,183,196-199]} \\
{[113]} \\
{[81,181]} \\
{[95]} \\
{[129]}\end{array}$ \\
\hline Microbleeds, iron & $\begin{array}{c}\text { SWI, QSM } \\
\mathrm{T}_{2}{ }^{*} \\
\mathrm{~T}_{2}{ }^{*} \mathrm{~W}\end{array}$ & $\begin{array}{l}\text { arcA } \beta \text { mice } \\
\text { APP /PS1 mice } \\
\text { CVN-AD mice } \\
\text { Tg SwDI mice } \\
\text { APP23 mice }\end{array}$ & $\begin{array}{c}112,167,200] \\
{[168]} \\
{[81]} \\
{[166]} \\
{[165]}\end{array}$ \\
\hline Inflammation & $\mathrm{T}_{2}{ }^{*} \mathrm{w}, \mathrm{MPIOs}-\alpha \mathrm{VCAM}-1$ & APP/PS1 mice & [201] \\
\hline Cerebrovasculature & $\begin{array}{l}\text { QUTE-CE } \\
\text { DWI } \\
\text { MRA } \\
\text { MION } \\
\text { MRE }\end{array}$ & $\begin{array}{c}\text { APOE4 rats } \\
5 \times \text { FAD mice } \\
\text { arcA } \beta \text { mice } \\
\text { APP } / \text { PS1 mice } \\
\text { APP23 mice } \\
\text { APPswe mice } \\
5 \times \text { FAD mice } \\
5 \times \text { FAD mice } \\
\text { APP } / \text { PS } 1 \text { mice } \\
\text { APP23 mice }\end{array}$ & $\begin{array}{c}{[202]} \\
{[203]} \\
{[156,167,169]} \\
{[109,204]} \\
{[134,136]} \\
{[205]} \\
{[203]} \\
{[206]} \\
{[207]} \\
{[208]}\end{array}$ \\
\hline
\end{tabular}

CE, contrast enhanced; CV, cerebral viscoelastic; DKI, diffusional kurtosis imaging; DTI, diffusion tensor imaging; DWI, diffusion-weighted imaging; MFAME, multi-flip angle multi-echo; MION, monocrystalline iron oxide nanoparticle; MPIOs, micro-sized particles of iron oxide; VCAM-1, vascular cell adhesion molecule-1; MRA, magnetic resonance angiography; MRE, magnetic resonance elastography; qMTI, quantitative magnetization transfer imaging; QSM, quantitative susceptibility mapping; QUTE-CE, quantitative ultrashort time-to-echo, contrast enhanced; SWI, susceptibility-weighted imaging; w, weighted. 


\subsection{MR Angiography (MRA)}

MRA has been widely used in clinical settings as well as in small-animal imaging for assessing the cerebrovasculature abnormalities. Intracranial stenosis assessed by using MRA was observed in patients with cognitive impairment and AD [209,210]. Both time-offlight and contrast-enhanced (CE)-MRA have been applied in amyloidosis animal models (Table 3). The detection of vascular alterations by in vivo MRA and histology has been reported in APP/PS1, arcA $\beta$, APP/PS1, and APP23 mice $[30,115,134,136,156]$. Klohs et al. demonstrated a reduced density and remodeling of cerebral microvasculature in aged $\operatorname{arcA} \beta$ mice compared to wild-type mice by using CE-MRA [156] (Figure 2e-h). MR Q mapping assisted with SPIO further showed a reduced level of microvessel density in the brains of arc $A \beta$ mice compared to wild-type mice, correlating with the levels of $A \beta$ pathology [200]. Several MR techniques have been developed recently for assessing the cerebrovasculature and blood-brain barrier integrity [141, 201, 202]. Chang et al. reported using diffusion-weighted imaging assisted with monocrystalline iron oxide nanoparticle for assessing the abnormalities in the vessel size index, diameter, density, mean vesselweighted image, and blood volume fraction in $5 \times$ FAD mice compared to wild-type mice [203]. Leaston et al. showed early vascular abnormalities in APOE4 knock-in rats compared to wild-type rats by using quantitative ultra-short time-to-echo (QUTE) CEMRI [202]. MR elastography has been used to detect the impaired cerebral viscoelastic properties in $5 \times$ FAD, APP/PS1, and APP23 mice [206-208]. Montagne et al. demonstrated brain cerebrovascular inflammation by using $\mathrm{T}_{2}{ }^{*}$-weighted MRI assisted with micro-sized particles of iron oxide (MPIO) targeting vascular cell adhesion molecule 1 (VCAM-1) in APP/PS1 mice [201].

\section{Structural Imaging}

\subsection{Volumetric Imaging for Brain Atrophy}

In vivo MRI using $T_{1}$ and $T_{2}$ scans and histological evaluation has identified differences in the entire brain or regional brain volumes between amyloidosis animal models and wild-type littermates, including APP T714I, APP/PS1, APP/PS1 KI, $3 \times \mathrm{Tg}$, and TASTPM mice and McGill-R-Thy1-APP rats [117,154,171-174,179,180,211] (Table 3). Delatour et al. reported global atrophy and an enlarged cerebrospinal fluid (CSF) space in the posterior brain areas and the midbrain areas in fiber tracts in APP/PS1 mice compared to wild-type mice [172]. Badhwar et al. demonstrated an impaired spatial learning/memory-induced volume increase in the hippocampus of APP/J20 mice compared to wild-type mice [170].

\subsection{DTI}

Extensive myelin loss was observed in amyloidosis animal models as well as in individuals with $\mathrm{AD}$ by in vivo imaging as well as by using histopathological investigations [194,212,213]. Recent studies have shown that myelin loss drove A $\beta$ deposition and that enhancing myelin renewal in turn alleviated the cognitive deficits in APP/PS1 [214] and in $5 \times$ FAD mice [215]. Impairment in white matter integrity has been detected by using in vivo and ex vivo DTI MRI in APPswe, APP/PS1, TgCRND8, APP NL-G-F, $3 \times \mathrm{Tg}$, CVNAD, and $5 \times$ FAD mice compared to wild-type mice [81,91,95,184-186,189,191,196,216-218] (Table 3). In these studies, the DTI abnormalities were detectable prior to the anatomical changes becoming visible in structural MRI. Reduced fractional anisotropy (FA) and both reduced/increased radial diffusivity (RD) were reported in aged APPswe mice compared to wild-type mice $[186,188,193]$. In addition to DTI, diffusion kurtosis imaging (DKI) and quantitative magnetization transfer imaging (qMTI) have detected hippocampal alterations in APP/PS1 and APPswe mice compared to wild-type mice [182,184]. Falangola et al. and Zhou et al. reported basal forebrain cholinergic abnormalities, detected by DTI and DKI, in $3 \times \mathrm{Tg}$ mice compared to wild-type mice [183,192]. Kastyak-lbrahim et al. reported a lack of white matter pathology in the same mouse line [198]. Reduced FA has also been reported in the gray matter in the brain of $3 \times \mathrm{Tg}$, APP/PS1, and APP23 mice [91,121,188,194-196,219]. Colon-Perez et al. reported reduced levels of FA and RD and increased orientation disper- 
sion and intracellular volume fraction in the white matter and hippocampus of TgCRND8 mice compared to wild-type mice, by using in vivo DTI MRI at $11.1 \mathrm{~T}$ and the neurite orientation dispersion and density imaging (NODDI) analysis pipeline [113]. In the CVN-AD mice, the white matter impairment was also associated with microglia activation [95].

\section{Discussion}

With the increased availability of and technological development in small-animal MRI, there is a rapid advance in molecular, functional, and structural imaging in AD amyloidosis animal models. Preclinical brain imaging is facing the unique challenge of the gap between man and mouse/rat models. Species differences in size, cell type, structure, circuit, the levels of protein expression, and metabolism has hindered the translation of imaging biomarkers from small animals to humans. The extent to which the transgenic disease animal model recapitulates the disease biology has been discussed extensively [220-222]. The amyloid deposits formed in the mouse models over the life-span of 1-2 years is structurally different from that in aged patients with AD [223]. In addition, conflicting observations regarding the degree of pathology across different studies have been reported, such as white matter impairment by DTI $[92,224]$ and atrophy, probably due to the dynamic microstructural changes in various animal models [173].

The advantage of MRI molecular imaging stems from its superior resolution and improved signal-to-noise ratio, enabled by the development in high-field MRI and coil arrays. MRI provides versatile functional, structural, and molecular readouts and longitudinal, large field-of-view imaging capacity compared to other imaging modalities, such as two-photon microscopy, fluorescence molecular tomography, and optoacoustic microscopy [225-230]. The disadvantages and limitations of preclinical MRI methods include the following:

(1) Relatively low molecular sensitivity. Positron emission tomography (PET) provides excellent sensitivity in detecting receptors or molecules at the system level even in the $\mathrm{pM}-\mathrm{nM}$ range, although the resolution is suboptimal for the small-animal brain [231-233]. In the case of in vivo MEMRI, the high dose of manganese chloride required might lead to increased risk of acute toxicity in the liver, heart, and kidney, and therefore this has not been widely applied. SPIO-nanoparticle-based contrast agents require much smaller amounts of injection compared to Gd-contrast agents due to the higher MR relaxivity.

(2) Requirements in terms of magnetic field and scanning time. For instance, $A \beta$ plaque detection using endogenous CE-MRI methods requires a long scan time using high-field MRI to achieve sufficient image quality, which hinders the application for in vivo imaging.

(3) Confounders and limitations in functional imaging. fMRI in small animals is more challenging compared to that in the human brain [234,235]. For functional imaging, the imaging speed achievable by MRI is limited in reflecting the rapid neuronal processes compared to optical imaging [236]. In addition, the states of animal (whether they underwent imaging under awake or anesthetized free-breathing/ventilated condition) and the anesthetic used (e.g., isoflurane/ketamine) largely impact the functional readouts. Further application of $\mathrm{fMRI}$ in AD amyloidosis animals that are awake will improve the translational value of the results.

Additional knowledge gaps in MR imaging in AD amyloidosis animal models include the following:

(1) BBB integrity imaging: BBB impairment plays an important role in AD pathogenesis and neural dysfunction and is associated with cognitive decline [237-242]. However, conflicting data showing a lack of widespread BBB leakage have also been reported in several AD animal models [243]. Dynamic contrast-enhanced (DCE)-MRI has been used to detect the impaired BBB integrity in the hippocampus of patients with early AD [244]. Montagne et al. recently demonstrated impaired BBB integrity in $5 \times$ FAD and APOE4 mice compared to wild-type mice by using DCE-MRI assisted with Gd-DTPA [141] (Figure 2a-d) (Table 3). Dickie et al. reported that DCE-MRI failed to detect the difference between 
the TgF344 rats and wild-type rats at 18 months-of-age and that the increased BBB water permeability was detected by using multi-flip angle multi-echo (MFAME) water-exchange MRI in TgF344 rats compared to wild-type rats [245]. Using the same method, Dickie et al. further showed in a cross-sectional study that BBB water permeability was affected earlier in TgF344 rats (13-18 months-of-age) compared to that in wild-type rats in normal ageing (18-21 months-of-age) [246]. Further studies are required to establish non-invasive imaging tools for visualizing BBB integrity and to elucidate the degree of BBB impairment in AD animal models.

(2) Glymphatic system imaging: The glymphatic system has been shown to be important for the exchange of CSF with interstitial fluid and for the clearance of waste metabolites involving the aquaporin 4 water channel [247]. Emerging evidence suggests that glymphatic system dysfunction may contribute to the development of AD [247-250]. Recent studies by Da Mesquita et al. have shown impaired meningeal lymphatics in J20 and $5 \times$ FAD mice compared to wild-type mice, which affected the microglia responses and the effect of anti-A $\beta$ immunotherapy in these models [251,252]. DCE-MRI using Gd-based contrast agents have been developed to examine the brain-wide glymphatic system in both healthy and diseased brains in human [253,254] and in animal models [255-259]. In addition to DCE-MRI, DTI analysis along the perivascular space [260], phase alternate labeling with null recovery MRI [261], and $\mathrm{Mn}^{2+}$ nanoconstruct for MRI detection of CSF [262] are being developed for studying the interstitial and CSF flow kinetics in animal models. In vivo MR imaging for the glymphatic system in amyloidosis animal models remains to be demonstrated in future studies.

(3) Integrating MRI with plasma and CSF biomarkers: So far, few studies have evaluated the amyloidosis models by using MRI combined with peripheral biomarkers. Parent et al. demonstrated the link between functional connectivity abnormalities (rs-fMRI), hippocampal atrophy, and levels of CSF $A \beta_{1-42}$ and cognitive deficits in McGill-R-Thy1APP rats [116]. Using dynamic glucose-enhanced MRI, Huang et al. demonstrated an altered level of D-glucose in the brain parenchymal as well as in the CSF of aged APP/PS1 mice compared to wild-type mice [142]. The CSF and plasma biomarkers provide comprehensive readouts for the levels of $A \beta$, neuroinflammation, and neurodegeneration and may facilitate result extrapolation to human studies.

In summary, the multiplex MRI has significantly improved our understanding of the pathophysiology in AD amyloidosis animal models at a systematic level and has provided the possibility of non-invasive longitudinal monitoring of disease development.

Funding: R.N. received funding from Helmut Horten Stiftung, Vontobel Stiftung, and the University of Zurich, reference No. [MEDEF-20-021].

Conflicts of Interest: The author declares no conflict of interest.

\section{References}

1. Scheltens, P.; De Strooper, B.; Kivipelto, M.; Holstege, H.; Chételat, G.; Teunissen, C.E.; Cummings, J.; van der Flier, W.M. Alzheimer's disease. Lancet 2021, 397, 1577-1590. [CrossRef]

2. Haass, C.; Selkoe, D.J. Soluble protein oligomers in neurodegeneration: Lessons from the Alzheimer's amyloid beta-peptide. Nat. Rev. Mol. Cell. Biol. 2007, 8, 101-112. [CrossRef] [PubMed]

3. Jack, C.R., Jr.; Bennett, D.A.; Blennow, K.; Carrillo, M.C.; Dunn, B.; Haeberlein, S.B.; Holtzman, D.M.; Jagust, W.; Jessen, F.; Karlawish, J.; et al. NIA-AA Research Framework: Toward a biological definition of Alzheimer's disease. Alzheimers Dement. 2018, 14, 535-562. [CrossRef] [PubMed]

4. Dubois, B.; Villain, N.; Frisoni, G.B.; Rabinovici, G.D.; Sabbagh, M.; Cappa, S.; Bejanin, A.; Bombois, S.; Epelbaum, S.; Teichmann, M.; et al. Clinical diagnosis of Alzheimer's disease: Recommendations of the International Working Group. Lancet Neurol. 2021, 20, 484-496. [CrossRef]

5. Marutle, A.; Gillberg, P.-G.; Bergfors, A.; Yu, W.; Ni, R.; Nennesmo, I.; Voytenko, L.; Nordberg, A. 3 H-Deprenyl and 3 H-PIB autoradiography show different laminar distributions of astroglia and fibrillar $\beta$-amyloid in Alzheimer brain. J. Neuroinflamm. 2013, 10, 861. [CrossRef]

6. Frisoni, G.B.; Fox, N.C.; Jack, C.R., Jr.; Scheltens, P.; Thompson, P.M. The clinical use of structural MRI in Alzheimer disease. Nat. Rev. Neurol. 2010, 6, 67-77. [CrossRef] 
7. Fox, M.D.; Raichle, M.E. Spontaneous fluctuations in brain activity observed with functional magnetic resonance imaging. Nat. Rev. Neurosci. 2007, 8, 700-711. [CrossRef] [PubMed]

8. Massalimova, A.; Ni, R.; Nitsch, R.M.; Reisert, M.; von Elverfeldt, D.; Klohs, J. Diffusion Tensor Imaging Reveals Whole-Brain Microstructural Changes in the P301L Mouse Model of Tauopathy. Neurodegener. Dis. 2021, 20, 173-184. [CrossRef] [PubMed]

9. Radde, R.; Bolmont, T.; Kaeser, S.A.; Coomaraswamy, J.; Lindau, D.; Stoltze, L.; Calhoun, M.E.; Jaggi, F.; Wolburg, H.; Gengler, S.; et al. Abeta42-driven cerebral amyloidosis in transgenic mice reveals early and robust pathology. EMBO Rep. 2006, 7, $940-946$. [CrossRef]

10. Hsiao, K.; Chapman, P.; Nilsen, S.; Eckman, C.; Harigaya, Y.; Younkin, S.; Yang, F.; Cole, G. Correlative memory deficits, Abeta elevation, and amyloid plaques in transgenic mice. Science 1996, 274, 99-102. [CrossRef]

11. Mucke, L.; Masliah, E.; Yu, G.Q.; Mallory, M.; Rockenstein, E.M.; Tatsuno, G.; Hu, K.; Kholodenko, D.; Johnson-Wood, K.; McConlogue, L. High-level neuronal expression of abeta 1-42 in wild-type human amyloid protein precursor transgenic mice: Synaptotoxicity without plaque formation. J. Neurosci. 2000, 20, 4050-4058. [CrossRef] [PubMed]

12. Richards, J.G.; Higgins, G.A.; Ouagazzal, A.M.; Ozmen, L.; Kew, J.N.; Bohrmann, B.; Malherbe, P.; Brockhaus, M.; Loetscher, H.; Czech, C.; et al. PS2APP transgenic mice, coexpressing hPS2mut and hAPPswe, show age-related cognitive deficits associated with discrete brain amyloid deposition and inflammation. J. Neurosci. 2003, 23, 8989-9003. [CrossRef] [PubMed]

13. Sturchler-Pierrat, C.; Abramowski, D.; Duke, M.; Wiederhold, K.H.; Mistl, C.; Rothacher, S.; Ledermann, B.; Bürki, K.; Frey, P.; Paganetti, P.A.; et al. Two amyloid precursor protein transgenic mouse models with Alzheimer disease-like pathology. Proc. Natl. Acad. Sci. USA 1997, 94, 13287-13292. [CrossRef] [PubMed]

14. Saito, T.; Matsuba, Y.; Mihira, N.; Takano, J.; Nilsson, P.; Itohara, S.; Iwata, N.; Saido, T.C. Single App knock-in mouse models of Alzheimer's disease. Nat. Neurosci. 2014, 17, 661-663. [CrossRef]

15. Serneels, L.; T'Syen, D.; Perez-Benito, L.; Theys, T.; Holt, M.G.; De Strooper, B. Modeling the $\beta$-secretase cleavage site and humanizing amyloid-beta precursor protein in rat and mouse to study Alzheimer's disease. Mol. Neurodegener. 2020, 15, 60. [CrossRef]

16. Sato, K.; Watamura, N.; Fujioka, R.; Mihira, N.; Sekiguchi, M.; Nagata, K.; Ohshima, T.; Saito, T.; Saido, T.C.; Sasaguri, H. A third-generation mouse model of Alzheimer's disease shows early and increased cored plaque pathology composed of wild-type human amyloid $\beta$ peptide. J. Biol. Chem. 2021, 297, 101004. [CrossRef]

17. Baglietto-Vargas, D.; Forner, S.; Cai, L.; Martini, A.C.; Trujillo-Estrada, L.; Swarup, V.; Nguyen, M.M.T.; Do Huynh, K.; Javonillo, D.I.; Tran, K.M.; et al. Generation of a humanized A $\beta$ expressing mouse demonstrating aspects of Alzheimer's disease-like pathology. Nat. Commun. 2021, 12, 2421. [CrossRef]

18. Lesné, S.; Koh, M.T.; Kotilinek, L.; Kayed, R.; Glabe, C.G.; Yang, A.; Gallagher, M.; Ashe, K.H. A specific amyloid- $\beta$ protein assembly in the brain impairs memory. Nature 2006, 440, 352-357. [CrossRef]

19. Shankar, G.M.; Li, S.; Mehta, T.H.; Garcia-Munoz, A.; Shepardson, N.E.; Smith, I.; Brett, F.M.; Farrell, M.A.; Rowan, M.J.; Lemere, C.A.; et al. Amyloid- $\beta$ protein dimers isolated directly from Alzheimer's brains impair synaptic plasticity and memory. Nat. Med. 2008, 14, 837-842. [CrossRef]

20. Oakley, H.; Cole, S.L.; Logan, S.; Maus, E.; Shao, P.; Craft, J.; Guillozet-Bongaarts, A.; Ohno, M.; Disterhoft, J.; Van Eldik, L.; et al. Intraneuronal beta-amyloid aggregates, neurodegeneration, and neuron loss in transgenic mice with five familial Alzheimer's disease mutations: Potential factors in amyloid plaque formation. J. Neurosci. 2006, 26, 10129-10140. [CrossRef]

21. Oddo, S.; Caccamo, A.; Shepherd, J.D.; Murphy, M.P.; Golde, T.E.; Kayed, R.; Metherate, R.; Mattson, M.P.; Akbari, Y.; LaFerla, F.M. Triple-transgenic model of Alzheimer's disease with plaques and tangles: Intracellular Abeta and synaptic dysfunction. Neuron 2003, 39, 409-421. [CrossRef]

22. Cohen, R.M.; Rezai-Zadeh, K.; Weitz, T.M.; Rentsendorj, A.; Gate, D.; Spivak, I.; Bholat, Y.; Vasilevko, V.; Glabe, C.G.; Breunig, J.J.; et al. A transgenic Alzheimer rat with plaques, tau pathology, behavioral impairment, oligomeric a $\beta$, and frank neuronal loss. J. Neurosci. 2013, 33, 6245-6256. [CrossRef] [PubMed]

23. Jack, C.R., Jr.; Wengenack, T.M.; Reyes, D.A.; Garwood, M.; Curran, G.L.; Borowski, B.J.; Lin, J.; Preboske, G.M.; Holasek, S.S.; Adriany, G.; et al. In vivo magnetic resonance microimaging of individual amyloid plaques in Alzheimer's transgenic mice. J. Neurosci. 2005, 25, 10041-10048. [CrossRef] [PubMed]

24. Maier, F.C.; Keller, M.D.; Bukala, D.; Bender, B.; Mannheim, J.G.; Brereton, I.M.; Galloway, G.J.; Pichler, B.J. Quantification of $\beta$-Amyloidosis and rCBF with Dedicated PET, 7 T MR Imaging, and High-Resolution Microscopic MR Imaging at 16.4 T in APP23 Mice. J. Nucl. Med. 2015, 56, 1593-1599. [CrossRef]

25. Bigot, C.; Vanhoutte, G.; Verhoye, M.; Van der Linden, A. Magnetization transfer contrast imaging reveals amyloid pathology in Alzheimer's disease transgenic mice. NeuroImage 2014, 87, 111-119. [CrossRef]

26. Pérez-Torres, C.J.; Reynolds, J.O.; Pautler, R.G. Use of magnetization transfer contrast MRI to detect early molecular pathology in Alzheimer's disease. Magn. Reson. Med. 2014, 71, 333-338. [CrossRef]

27. Jahng, G.H.; Choi, W.; Chung, J.J.; Kim, S.T.; Rhee, H.Y. Mapping Exchangeable Protons to Monitor Protein Alterations in the Brain of an Alzheimer's Disease Mouse Model by Using MRI. Curr. Alzheimer Res. 2018, 15, 1343-1353. [CrossRef] [PubMed]

28. Kim, J.H.; Ha, T.L.; Im, G.H.; Yang, J.; Seo, S.W.; Chung, J.J.; Chae, S.Y.; Lee, I.S.; Lee, J.H. Magnetic resonance imaging for monitoring therapeutic response in a transgenic mouse model of Alzheimer's disease using voxel-based analysis of amyloid plaques. NeuroReport 2014, 25, 211-218. [CrossRef] 
29. Li, L.; Wang, X.-Y.; Gao, F.-B.; Wang, L.; Xia, R.; Li, Z.-X.; Xing, W.; Tang, B.-S.; Zeng, Y.; Zhou, G.-F.; et al. Magnetic resonance T2 relaxation time at 7 Tesla associated with amyloid $\beta$ pathology and age in a double-transgenic mouse model of Alzheimer's disease. Neurosci. Lett. 2016, 610, 92-97. [CrossRef]

30. El Tayara Nel, T.; Volk, A.; Dhenain, M.; Delatour, B. Transverse relaxation time reflects brain amyloidosis in young APP/PS1 transgenic mice. Magn. Reson. Med. 2007, 58, 179-184. [CrossRef] [PubMed]

31. Everett, J.; Lermyte, F.; Brooks, J.; Tjendana-Tjhin, V.; Plascencia-Villa, G.; Hands-Portman, I.; Donnelly, J.M.; Billimoria, K.; Perry, G.; Zhu, X.; et al. Biogenic metallic elements in the human brain? Sci. Adv. 2021, 7, eabf6707. [CrossRef] [PubMed]

32. Gong, N.J.; Dibb, R.; Bulk, M.; van der Weerd, L.; Liu, C. Imaging beta amyloid aggregation and iron accumulation in Alzheimer's disease using quantitative susceptibility mapping MRI. NeuroImage 2019, 191, 176-185. [CrossRef] [PubMed]

33. Chamberlain, R.; Reyes, D.; Curran, G.L.; Marjanska, M.; Wengenack, T.M.; Poduslo, J.F.; Garwood, M.; Jack, C.R., Jr. Comparison of amyloid plaque contrast generated by T2-weighted, T2*-weighted, and susceptibility-weighted imaging methods in transgenic mouse models of Alzheimer's disease. Magn. Reson. Med. 2009, 61, 1158-1164. [CrossRef] [PubMed]

34. Santin, M.D.; Vandenberghe, M.E.; Herard, A.S.; Pradier, L.; Cohen, C.; Debeir, T.; Delzescaux, T.; Rooney, T.; Dhenain, M. In Vivo Detection of Amyloid Plaques by Gadolinium-Stained MRI Can Be Used to Demonstrate the Efficacy of an Anti-amyloid Immunotherapy. Front. Aging Neurosci. 2016, 8, 55. [CrossRef]

35. Wadghiri, Y.Z.; Sigurdsson, E.M.; Sadowski, M.; Elliott, J.I.; Li, Y.; Scholtzova, H.; Tang, C.Y.; Aguinaldo, G.; Pappolla, M.; Duff, K.; et al. Detection of Alzheimer's amyloid in transgenic mice using magnetic resonance microimaging. Magn. Reson. Med. 2003, 50, 293-302. [CrossRef] [PubMed]

36. Sigurdsson, E.M.; Wadghiri, Y.Z.; Mosconi, L.; Blind, J.A.; Knudsen, E.; Asuni, A.; Scholtzova, H.; Tsui, W.H.; Li, Y.; Sadowski, M.; et al. A non-toxic ligand for voxel-based MRI analysis of plaques in AD transgenic mice. Neurobiol. Aging 2008, 29, 836-847. [CrossRef] [PubMed]

37. Wang, X.; Chan, H.N.; Desbois, N.; Gros, C.P.; Bolze, F.; Li, Y.; Li, H.W.; Wong, M.S. Multimodal Theranostic Cyanine-Conjugated Gadolinium(III) Complex for In Vivo Imaging of Amyloid- $\beta$ in an Alzheimer's Disease Mouse Model. ACS Appl. Mater. Interfaces 2021, 13, 18525-18532. [CrossRef]

38. Badachhape, A.; Parekh, P.A.; Mu, Q.; Bhavane, R.; Srivastava, M.; Stupin, I.; Bhandari, P.; Devkota, L.; Tanifum, E.; Ghaghada, K.; et al. A novel MRI contrast agent for identifying hyperphosphorylative neurons as a marker of future tau pathology. Alzheimer. Dement. 2020, 16, e041080. [CrossRef]

39. Wengenack, T.M.; Jack, C.R., Jr.; Garwood, M.; Poduslo, J.F. MR microimaging of amyloid plaques in Alzheimer's disease transgenic mice. Eur. J. Nucl. Med. Mol. Imaging 2008, 35 (Suppl. S1), S82-S88. [CrossRef]

40. Wadghiri, Y.Z.; Li, J.; Wang, J.; Hoang, D.M.; Sun, Y.; Xu, H.; Tsui, W.; Li, Y.; Boutajangout, A.; Wang, A.; et al. Detection of amyloid plaques targeted by bifunctional USPIO in Alzheimer's disease transgenic mice using magnetic resonance microimaging. PLoS ONE 2013, 8, e57097. [CrossRef]

41. Tafoya, M.A.; Madi, S.; Sillerud, L.O. Superparamagnetic nanoparticle-enhanced MRI of Alzheimer's disease plaques and activated microglia in 3X transgenic mouse brains: Contrast optimization. J. Magn. Reson. Imaging 2017, 46, 574-588. [CrossRef] [PubMed]

42. Sillerud, L.O.; Solberg, N.O.; Chamberlain, R.; Orlando, R.A.; Heidrich, J.E.; Brown, D.C.; Brady, C.I.; Vander Jagt, T.A.; Garwood, M.; Vander Jagt, D.L. SPION-enhanced magnetic resonance imaging of Alzheimer's disease plaques in A $\beta P P / P S-1$ transgenic mouse brain. J. Alzheimers Dis. 2013, 34, 349-365. [CrossRef] [PubMed]

43. Beckmann, N.; Gérard, C.; Abramowski, D.; Cannet, C.; Staufenbiel, M. Noninvasive magnetic resonance imaging detection of cerebral amyloid angiopathy-related microvascular alterations using superparamagnetic iron oxide particles in APP transgenic mouse models of Alzheimer's disease: Application to passive Abeta immunotherapy. J. Neurosci. 2011, 31, 1023-1031. [CrossRef]

44. Poduslo, J.F.; Hultman, K.L.; Curran, G.L.; Preboske, G.M.; Chamberlain, R.; Marjańska, M.; Garwood, M.; Jack, C.R., Jr.; Wengenack, T.M. Targeting vascular amyloid in arterioles of Alzheimer disease transgenic mice with amyloid $\beta$ protein antibodycoated nanoparticles. J. Neuropathol. Exp. Neurol. 2011, 70, 653-661. [CrossRef] [PubMed]

45. Dudeffant, C.; Vandesquille, M.; Herbert, K.; Garin, C.M.; Alves, S.; Blanchard, V.; Comoy, E.E.; Petit, F.; Dhenain, M. Contrastenhanced MR microscopy of amyloid plaques in five mouse models of amyloidosis and in human Alzheimer's disease brains. Sci. Rep. 2017, 7, 4955. [CrossRef] [PubMed]

46. Kim, E.; Di Censo, D.; Baraldo, M.; Simmons, C.; Rosa, I.; Randall, K.; Ballard, C.; Dickie, B.R.; Williams, S.C.R.; Killick, R.; et al. In vivo multi-parametric manganese-enhanced MRI for detecting amyloid plaques in rodent models of Alzheimer's disease. Sci. Rep. 2021, 11, 12419. [CrossRef]

47. Nasr, S.H.; Kouyoumdjian, H.; Mallett, C.; Ramadan, S.; Zhu, D.C.; Shapiro, E.M.; Huang, X. Detection of $\beta$-Amyloid by Sialic Acid Coated Bovine Serum Albumin Magnetic Nanoparticles in a Mouse Model of Alzheimer's Disease. Small 2018, 14, 1701828. [CrossRef] [PubMed]

48. Higuchi, M.; Iwata, N.; Matsuba, Y.; Sato, K.; Sasamoto, K.; Saido, T.C. 19F and 1H MRI detection of amyloid beta plaques in vivo. Nat. Neurosci. 2005, 8, 527-533. [CrossRef]

49. Yousaf, M.; Ahmad, M.; Bhatti, I.A.; Nasir, A.; Hasan, M.; Jian, X.; Kalantar-Zadeh, K.; Mahmood, N. In Vivo and In Vitro Monitoring of Amyloid Aggregation via BSA@FGQDs Multimodal Probe. ACS Sens. 2019, 4, 200-210. [CrossRef] 
50. Amatsubo, T.; Morikawa, S.; Inubushi, T.; Urushitani, M.; Taguchi, H.; Shirai, N.; Hirao, K.; Kato, M.; Morino, K.; Kimura, H.; et al. Trifluoromethoxy-benzylated ligands improve amyloid detection in the brain using (19)F magnetic resonance imaging. Neurosci. Res. 2009, 63, 76-81. [CrossRef]

51. Yanagisawa, D.; Ibrahim, N.F.; Taguchi, H.; Morikawa, S.; Tomiyama, T.; Tooyama, I. Fluorine-19 Magnetic Resonance Imaging for Detection of Amyloid $\beta$ Oligomers Using a Keto Form of Curcumin Derivative in a Mouse Model of Alzheimer's Disease. Molecules 2021, 26, 1362. [CrossRef]

52. Yanagisawa, D.; Amatsubo, T.; Morikawa, S.; Taguchi, H.; Urushitani, M.; Shirai, N.; Hirao, K.; Shiino, A.; Inubushi, T.; Tooyama, I. In vivo detection of amyloid $\beta$ deposition using ${ }^{19} \mathrm{~F}$ magnetic resonance imaging with a ${ }^{19} \mathrm{~F}$-containing curcumin derivative in a mouse model of Alzheimer's disease. Neuroscience 2011, 184, 120-127. [CrossRef]

53. Viola, K.L.; Sbarboro, J.; Sureka, R.; De, M.; Bicca, M.A.; Wang, J.; Vasavada, S.; Satpathy, S.; Wu, S.; Joshi, H.; et al. Towards non-invasive diagnostic imaging of early-stage Alzheimer's disease. Nat. Nanotechnol. 2015, 10, 91-98. [CrossRef]

54. Rozema, N.B.; Procissi, D.; Bertolino, N.; Viola, K.L.; Nandwana, V.; Abdul, N.; Pribus, S.; Dravid, V.; Klein, W.L.; Disterhoft, J.F.; et al. A $\beta$ oligomer induced cognitive impairment and evaluation of ACU193-MNS-based MRI in rabbit. Alzheimers Dement. 2020, 6, e12087. [CrossRef] [PubMed]

55. Sehlin, D.; Fang, X.T.; Cato, L.; Antoni, G.; Lannfelt, L.; Syvänen, S. Antibody-based PET imaging of amyloid beta in mouse models of Alzheimer's disease. Nat. Commun. 2016, 7, 10759. [CrossRef] [PubMed]

56. Liu, X.G.; Zhang, L.; Lu, S.; Liu, D.Q.; Zhang, L.X.; Yu, X.L.; Liu, R.T. Multifunctional Superparamagnetic Iron Oxide Nanoparticles Conjugated with A $\beta$ Oligomer-Specific scFv Antibody and Class A Scavenger Receptor Activator Show Early Diagnostic Potentials for Alzheimer's Disease. Int. J. Nanomed. 2020, 15, 4919-4932. [CrossRef]

57. Dong, C.M.; Guo, A.S.; To, A.; Chan, K.W.Y.; Chow, A.S.F.; Bian, L.; Leong, A.T.L.; Wu, E.X. Early Detection of Amyloid $\beta$ Pathology in Alzheimer's Disease by Molecular MRI. In Proceedings of the 2020 42nd Annual International Conference of the IEEE Engineering in Medicine \& Biology Society (EMBC), Montreal, QC, Canada, 20-24 July 2020; pp. 1100-1103. [CrossRef]

58. Cheng, K.K.; Chan, P.S.; Fan, S.; Kwan, S.M.; Yeung, K.L.; Wáng, Y.X.; Chow, A.H.; Wu, E.X.; Baum, L. Curcumin-conjugated magnetic nanoparticles for detecting amyloid plaques in Alzheimer's disease mice using magnetic resonance imaging (MRI). Biomaterials 2015, 44, 155-172. [CrossRef] [PubMed]

59. Spencer, N.G.; Bridges, L.R.; Elderfield, K.; Amir, K.; Austen, B.; Howe, F.A. Quantitative evaluation of MRI and histological characteristics of the 5xFAD Alzheimer mouse brain. NeuroImage 2013, 76, 108-115. [CrossRef]

60. Falangola, M.F.; Dyakin, V.V.; Lee, S.P.; Bogart, A.; Babb, J.S.; Duff, K.; Nixon, R.; Helpern, J.A. Quantitative MRI reveals aging-associated T2 changes in mouse models of Alzheimer's disease. NMR Biomed. 2007, 20, 343-351. [CrossRef]

61. Helpern, J.A.; Lee, S.P.; Falangola, M.F.; Dyakin, V.V.; Bogart, A.; Ardekani, B.; Duff, K.; Branch, C.; Wisniewski, T.; de Leon, M.J.; et al. MRI assessment of neuropathology in a transgenic mouse model of Alzheimer's disease. Magn. Reson. Med. 2004, 51, 794-798. [CrossRef] [PubMed]

62. Braakman, N.; Matysik, J.; van Duinen, S.G.; Verbeek, F.; Schliebs, R.; de Groot, H.J.; Alia, A. Longitudinal assessment of Alzheimer's beta-amyloid plaque development in transgenic mice monitored by in vivo magnetic resonance microimaging. J. Magn. Reson. Imaging 2006, 24, 530-536. [CrossRef]

63. Wengenack, T.M.; Reyes, D.A.; Curran, G.L.; Borowski, B.J.; Lin, J.; Preboske, G.M.; Holasek, S.S.; Gilles, E.J.; Chamberlain, R.; Marjanska, M.; et al. Regional differences in MRI detection of amyloid plaques in AD transgenic mouse brain. NeuroImage 2011, 54, 113-122. [CrossRef] [PubMed]

64. Vanhoutte, G.; Dewachter, I.; Borghgraef, P.; Van Leuven, F.; Van der Linden, A. Noninvasive in vivo MRI detection of neuritic plaques associated with iron in APP[V717I] transgenic mice, a model for Alzheimer's disease. Magn. Reson. Med. 2005, 53, 607-613. [CrossRef] [PubMed]

65. Raymond, S.B.; Treat, L.H.; Dewey, J.D.; McDannold, N.J.; Hynynen, K.; Bacskai, B.J. Ultrasound enhanced delivery of molecular imaging and therapeutic agents in Alzheimer's disease mouse models. PLoS ONE 2008, 3, e2175. [CrossRef] [PubMed]

66. Dhenain, M.; El Tannir El Tayara, N.; . Wu, T.D.; Guégan, M.; Volk, A.; Quintana, C.; Delatour, B. Characterization of in vivo MRI detectable thalamic amyloid plaques from APP/PS1 mice. Neurobiol. Aging 2009, 30, 41-53. [CrossRef]

67. Faber, C.; Zahneisen, B.; Tippmann, F.; Schroeder, A.; Fahrenholz, F. Gradient-echo and CRAZED imaging for minute detection of Alzheimer plaques in an APPV717I x ADAM10-dn mouse model. Magn. Reson. Med. 2007, 57, 696-703. [CrossRef]

68. Palop, J.J.; Chin, J.; Roberson, E.D.; Wang, J.; Thwin, M.T.; Bien-Ly, N.; Yoo, J.; Ho, K.O.; Yu, G.Q.; Kreitzer, A.; et al. Aberrant excitatory neuronal activity and compensatory remodeling of inhibitory hippocampal circuits in mouse models of Alzheimer's disease. Neuron 2007, 55, 697-711. [CrossRef]

69. Latif-Hernandez, A.; Sabanov, V.; Ahmed, T.; Craessaerts, K.; Saito, T.; Saido, T.; Balschun, D. The two faces of synaptic failure in App(NL-G-F) knock-in mice. Alzheimers Res. 2020, 12, 100. [CrossRef] [PubMed]

70. Jun, H.; Bramian, A.; Soma, S.; Saito, T.; Saido, T.C.; Igarashi, K.M. Disrupted Place Cell Remapping and Impaired Grid Cells in a Knockin Model of Alzheimer's Disease. Neuron 2020, 107, 1095-1112.e6. [CrossRef]

71. Pervolaraki, E.; Hall, S.P.; Foresteire, D.; Saito, T.; Saido, T.C.; Whittington, M.A.; Lever, C.; Dachtler, J. Insoluble A $\beta$ overexpression in an App knock-in mouse model alters microstructure and gamma oscillations in the prefrontal cortex, affecting anxiety-related behaviours. Dis. Models Mech. 2019, 12, dmm040550. [CrossRef] 
72. Busche, M.A.; Eichhoff, G.; Adelsberger, H.; Abramowski, D.; Wiederhold, K.H.; Haass, C.; Staufenbiel, M.; Konnerth, A.; Garaschuk, O. Clusters of hyperactive neurons near amyloid plaques in a mouse model of Alzheimer's disease. Science 2008, 321, 1686-1689. [CrossRef]

73. Zott, B.; Simon, M.M.; Hong, W.; Unger, F.; Chen-Engerer, H.J.; Frosch, M.P.; Sakmann, B.; Walsh, D.M.; Konnerth, A. A vicious cycle of $\beta$ amyloid-dependent neuronal hyperactivation. Science 2019, 365, 559-565. [CrossRef] [PubMed]

74. Tarantini, S.; Fulop, G.A.; Kiss, T.; Farkas, E.; Zölei-Szénási, D.; Galvan, V.; Toth, P.; Csiszar, A.; Ungvari, Z.; Yabluchanskiy, A. Demonstration of impaired neurovascular coupling responses in TG2576 mouse model of Alzheimer's disease using functional laser speckle contrast imaging. Geroscience 2017, 39, 465-473. [CrossRef] [PubMed]

75. Ben-Nejma, I.R.H.; Keliris, A.J.; Daans, J.; Ponsaerts, P.; Verhoye, M.; Van der Linden, A.; Keliris, G.A. Increased soluble amyloid-beta causes early aberrant brain network hypersynchronisation in a mature-onset mouse model of amyloidosis. Acta Neuropathol. Commun. 2019, 7, 180. [CrossRef]

76. Schroeder, M.P.; Weiss, C.; Procissi, D.; Wang, L.; Disterhoft, J.F. Activity-induced manganese-dependent MRI (AIM-MRI) and functional MRI in awake rabbits during somatosensory stimulation. NeuroImage 2016, 126, 72-80. [CrossRef]

77. Aoki, I.; Tanaka, C.; Takegami, T.; Ebisu, T.; Umeda, M.; Fukunaga, M.; Fukuda, K.; Silva, A.C.; Koretsky, A.P.; Naruse, S. Dynamic activity-induced manganese-dependent contrast magnetic resonance imaging (DAIM MRI). Magn. Reson. Med. 2002, 48, 927-933. [CrossRef] [PubMed]

78. Androuin, A.; Abada, Y.-s.; Ly, M.; Santin, M.; Petiet, A.; Epelbaum, S.; Bertrand, A.; Delatour, B. Activity-induced MEMRI cannot detect functional brain anomalies in the APPxPS1-Ki mouse model of Alzheimer's disease. Sci. Rep. 2019, 9, 1140. [CrossRef] [PubMed]

79. Yoshikawa, M.; Soeda, Y.; Michikawa, M.; Almeida, O.F.X.; Takashima, A. Tau Depletion in APP Transgenic Mice Attenuates Task-Related Hyperactivation of the Hippocampus and Differentially Influences Locomotor Activity and Spatial Memory. Front. Neurosci. 2018, 12, 124. [CrossRef]

80. Nie, B.; Wu, D.; Liang, S.; Liu, H.; Sun, X.; Li, P.; Huang, Q.; Zhang, T.; Feng, T.; Ye, S.; et al. A stereotaxic MRI template set of mouse brain with fine sub-anatomical delineations: Application to MEMRI studies of 5XFAD mice. Magn. Reson. Imaging 2019, 57, 83-94. [CrossRef]

81. Badea, A.; Delpratt, N.A.; Anderson, R.J.; Dibb, R.; Qi, Y.; Wei, H.; Liu, C.; Wetsel, W.C.; Avants, B.B.; Colton, C. Multivariate MR biomarkers better predict cognitive dysfunction in mouse models of Alzheimer's disease. Magn. Reson. Imaging 2019, 60, 52-67. [CrossRef]

82. Saar, G.; Cheng, N.; Belluscio, L.; Koretsky, A.P. Laminar specific detection of APP induced neurodegeneration and recovery using MEMRI in an olfactory based Alzheimer's disease mouse model. NeuroImage 2015, 118, 183-192. [CrossRef] [PubMed]

83. Smith, K.D.B.; Kallhoff, V.; Zheng, H.; Pautler, R.G. In vivo axonal transport rates decrease in a mouse model of Alzheimer's disease. NeuroImage 2007, 35, 1401-1408. [CrossRef] [PubMed]

84. Wang, F.H.; Appelkvist, P.; Klason, T.; Gissberg, O.; Bogstedt, A.; Eliason, K.; Martinsson, S.; Briem, S.; Andersson, A.; Visser, S.A.; et al. Decreased axonal transport rates in the Tg2576 APP transgenic mouse: Improvement with the gamma-secretase inhibitor MRK-560 as detected by manganese-enhanced MRI. Eur. J. Neurosci. 2012, 36, 3165-3172. [CrossRef] [PubMed]

85. Kim, J.; Choi, I.Y.; Michaelis, M.L.; Lee, P. Quantitative in vivo measurement of early axonal transport deficits in a triple transgenic mouse model of Alzheimer's disease using manganese-enhanced MRI. NeuroImage 2011, 56, 1286-1292. [CrossRef]

86. Medina, C.S.; Uselman, T.W.; Barto, D.R.; Cháves, F.; Jacobs, R.E.; Bearer, E.L. Decoupling the Effects of the Amyloid Precursor Protein From Amyloid- $\beta$ Plaques on Axonal Transport Dynamics in the Living Brain. Front. Cell. Neurosci. 2019, $13,501$. [CrossRef] [PubMed]

87. Grandjean, J.; Canella, C.; Anckaerts, C.; Ayranc1, G.; Bougacha, S.; Bienert, T.; Buehlmann, D.; Coletta, L.; Gallino, D.; Gass, N.; et al. Common functional networks in the mouse brain revealed by multi-centre resting-state fMRI analysis. NeuroImage 2020, 205, 116278. [CrossRef]

88. Grandjean, J.; Schroeter, A.; He, P.; Tanadini, M.; Keist, R.; Krstic, D.; Konietzko, U.; Klohs, J.; Nitsch, R.M.; Rudin, M. Early alterations in functional connectivity and white matter structure in a transgenic mouse model of cerebral amyloidosis. J. Neurosci. 2014, 34, 13780-13789. [CrossRef]

89. Shah, D.; Praet, J.; Latif Hernandez, A.; Höfling, C.; Anckaerts, C.; Bard, F.; Morawski, M.; Detrez, J.R.; Prinsen, E.; Villa, A.; et al. Early pathologic amyloid induces hypersynchrony of BOLD resting-state networks in transgenic mice and provides an early therapeutic window before amyloid plaque deposition. Alzheimers Dement. 2016, 12, 964-976. [CrossRef]

90. Shah, D.; Latif-Hernandez, A.; Strooper, B.; Saito, T.; Saido, T.; Verhoye, M.; D’Hooge, R.; Van der Linden, A. Spatial reversal learning defect coincides with hypersynchronous telencephalic BOLD functional connectivity in APPNL-F/NL-F knock-in mice. Sci. Rep. 2018, 8, 6264. [CrossRef]

91. Manno, F.A.M.; Isla, A.G.; Manno, S.H.C.; Ahmed, I.; Cheng, S.H.; Barrios, F.A.; Lau, C. Early Stage Alterations in White Matter and Decreased Functional Interhemispheric Hippocampal Connectivity in the 3xTg Mouse Model of Alzheimer's Disease. Front. Aging Neurosci. 2019, 11, 39. [CrossRef] [PubMed]

92. Grandjean, J.; Derungs, R.; Kulic, L.; Welt, T.; Henkelman, M.; Nitsch, R.M.; Rudin, M. Complex interplay between brain function and structure during cerebral amyloidosis in APP transgenic mouse strains revealed by multi-parametric MRI comparison. NeuroImage 2016, 134, 1-11. [CrossRef] [PubMed] 
93. Sakurai, K.; Shintani, T.; Jomura, N.; Matsuda, T.; Sumiyoshi, A.; Hisatsune, T. Hyper BOLD Activation in Dorsal Raphe Nucleus of APP/PS1 Alzheimer's Disease Mouse during Reward-Oriented Drinking Test under Thirsty Conditions. Sci. Rep. 2020, 10, 3915. [CrossRef] [PubMed]

94. Sanganahalli, B.G.; Herman, P.; Behar, K.L.; Blumenfeld, H.; Rothman, D.L.; Hyder, F. Functional MRI and neural responses in a rat model of Alzheimer's disease. NeuroImage 2013, 79, 404-411. [CrossRef] [PubMed]

95. Badea, A.; Kane, L.; Anderson, R.J.; Qi, Y.; Foster, M.; Cofer, G.P.; Medvitz, N.; Buckley, A.F.; Badea, A.K.; Wetsel, W.C.; et al. The fornix provides multiple biomarkers to characterize circuit disruption in a mouse model of Alzheimer's disease. NeuroImage 2016, 142, 498-511. [CrossRef]

96. Latif-Hernandez, A.; Shah, D.; Craessaerts, K.; Saido, T.; Saito, T.; De Strooper, B.; Van der Linden, A.; D'Hooge, R. Subtle behavioral changes and increased prefrontal-hippocampal network synchronicity in APP(NL-G-F) mice before prominent plaque deposition. Behav. Brain Res. 2019, 364, 431-441. [CrossRef] [PubMed]

97. Shah, D.; Jonckers, E.; Praet, J.; Vanhoutte, G.; Delgado y Palacios, R.; Bigot, C.; D'Souza, D.V.; Verhoye, M.; Van der Linden, A. Resting State fMRI Reveals Diminished Functional Connectivity in a Mouse Model of Amyloidosis. PLoS ONE 2013, 8, e84241. [CrossRef] [PubMed]

98. Gail Canter, R.; Huang, W.C.; Choi, H.; Wang, J.; Ashley Watson, L.; Yao, C.G.; Abdurrob, F.; Bousleiman, S.M.; Young, J.Z.; Bennett, D.A.; et al. 3D mapping reveals network-specific amyloid progression and subcortical susceptibility in mice. Commun. Biol. 2019, 2, 360. [CrossRef]

99. Tudela, R.; Muñoz-Moreno, E.; Sala-Llonch, R.; López-Gil, X.; Soria, G. Resting State Networks in the TgF344-AD Rat Model of Alzheimer's Disease Are Altered From Early Stages. Front. Aging Neurosci. 2019, 11, 213. [CrossRef] [PubMed]

100. Haller, S.; Zaharchuk, G.; Thomas, D.L.; Lovblad, K.O.; Barkhof, F.; Golay, X. Arterial Spin Labeling Perfusion of the Brain: Emerging Clinical Applications. Radiology 2016, 281, 337-356. [CrossRef]

101. Cruz Hernández, J.C.; Bracko, O.; Kersbergen, C.J.; Muse, V.; Haft-Javaherian, M.; Berg, M.; Park, L.; Vinarcsik, L.K.; Ivasyk, I.; Rivera, D.A.; et al. Neutrophil adhesion in brain capillaries reduces cortical blood flow and impairs memory function in Alzheimer's disease mouse models. Nat. Neurosci. 2019, 22, 413-420. [CrossRef]

102. Guo, Y.; Li, X.; Zhang, M.; Chen, N.; . Wu, S.; Lei, J.; Wang, Z.; Wang, R.; Wang, J.; Liu, H. Age- and brain region-associated alterations of cerebral blood flow in early Alzheimer's disease assessed in A $\beta$ PPSWE/PS1 $\triangle E 9$ transgenic mice using arterial spin labeling. Mol. Med. Rep. 2019, 19, 3045-3052. [CrossRef] [PubMed]

103. Adlimoghaddam, A.; Snow, W.M.; Stortz, G.; Perez, C.; Djordjevic, J.; Goertzen, A.L.; Ko, J.H.; Albensi, B.C. Regional hypometabolism in the 3xTg mouse model of Alzheimer's disease. Neurobiol. Dis. 2019, 127, 264-277. [CrossRef]

104. Ni, R.; Kindler, D.R.; Waag, R.; Rouault, M.; Ravikumar, P.; Nitsch, R.; Rudin, M.; Camici, G.G.; Liberale, L.; Kulic, L.; et al. fMRI Reveals Mitigation of Cerebrovascular Dysfunction by Bradykinin Receptors 1 and 2 Inhibitor Noscapine in a Mouse Model of Cerebral Amyloidosis. Front. Aging Neurosci. 2019, 11, 27. [CrossRef] [PubMed]

105. Ni, R.; Rudin, M.; Klohs, J. Cortical hypoperfusion and reduced cerebral metabolic rate of oxygen in the arcA $\beta$ mouse model of Alzheimer's disease. Photoacoustics 2018, 10, 38-47. [CrossRef]

106. Hébert, F.; Grand'maison, M.; Ho, M.K.; Lerch, J.P.; Hamel, E.; Bedell, B.J. Cortical atrophy and hypoperfusion in a transgenic mouse model of Alzheimer's disease. Neurobiol. Aging 2013, 34, 1644-1652. [CrossRef] [PubMed]

107. Massaad, C.A.; Amin, S.K.; Hu, L.; Mei, Y.; Klann, E.; Pautler, R.G. Mitochondrial Superoxide Contributes to Blood Flow and Axonal Transport Deficits in the Tg2576 Mouse Model of Alzheimer's Disease. PLoS ONE 2010, 5, e10561. [CrossRef]

108. Weidensteiner, C.; Metzger, F.; Bruns, A.; Bohrmann, B.; Kuennecke, B.; von Kienlin, M. Cortical hypoperfusion in the B6.PS2APP mouse model for Alzheimer's disease: Comprehensive phenotyping of vascular and tissular parameters by MRI. Magn. Reson. Med. 2009, 62, 35-45. [CrossRef]

109. Poisnel, G.; Hérard, A.S.; El Tannir El Tayara, N.; Bourrin, E.; Volk, A.; Kober, F.; Delatour, B.; Delzescaux, T.; Debeir, T.; Rooney, T.; et al. Increased regional cerebral glucose uptake in an APP/PS1 model of Alzheimer's disease. Neurobiol. Aging 2012, 33, 1995-2005. [CrossRef] [PubMed]

110. Luo, F.; Rustay, N.R.; Ebert, U.; Hradil, V.P.; Cole, T.B.; Llano, D.A.; Mudd, S.R.; Zhang, Y.; Fox, G.B.; Day, M. Characterization of 7- and 19-month-old Tg2576 mice using multimodal in vivo imaging: Limitations as a translatable model of Alzheimer's disease. Neurobiol. Aging 2012, 33, 933-944. [CrossRef]

111. Wiesmann, M.; Zerbi, V.; Jansen, D.; Lütjohann, D.; Veltien, A.; Heerschap, A.; Kiliaan, A.J. Hypertension, cerebrovascular impairment, and cognitive decline in aged A $\beta$ PP/PS1 mice. Theranostics 2017, 7, 1277-1289. [CrossRef] [PubMed]

112. Klohs, J.; Deistung, A.; Schweser, F.; Grandjean, J.; Dominietto, M.; Waschkies, C.; Nitsch, R.M.; Knuesel, I.; Reichenbach, J.R.; Rudin, M. Detection of cerebral microbleeds with quantitative susceptibility mapping in the ArcAbeta mouse model of cerebral amyloidosis. J. Cereb. Blood Flow Metab. 2011, 31, 2282-2292. [CrossRef]

113. Colon-Perez, L.M.; Ibanez, K.R.; Suarez, M.; Torroella, K.; Acuna, K.; Ofori, E.; Levites, Y.; Vaillancourt, D.E.; Golde, T.E.; Chakrabarty, P.; et al. Neurite orientation dispersion and density imaging reveals white matter and hippocampal microstructure changes produced by Interleukin-6 in the TgCRND8 mouse model of amyloidosis. NeuroImage 2019, 202, 116138. [CrossRef] [PubMed]

114. Anckaerts, C.; Blockx, I.; Summer, P.; Michael, J.; Hamaide, J.; Kreutzer, C.; Boutin, H.; Couillard-Després, S.; Verhoye, M.; Van der Linden, A. Early functional connectivity deficits and progressive microstructural alterations in the TgF344-AD rat model of Alzheimer's Disease: A longitudinal MRI study. Neurobiol. Dis. 2019, 124, 93-107. [CrossRef] [PubMed] 
115. Kara, F.; Belloy, M.E.; Voncken, R.; Sarwari, Z.; Garima, Y.; Anckaerts, C.; Langbeen, A.; Leysen, V.; Shah, D.; Jacobs, J.; et al. Long-term ovarian hormone deprivation alters functional connectivity, brain neurochemical profile and white matter integrity in the Tg2576 amyloid mouse model of Alzheimer's disease. Neurobiol. Aging 2021, 102, 139-150. [CrossRef]

116. Parent, M.J.; Zimmer, E.R.; Shin, M.; Kang, M.S.; Fonov, V.S.; Mathieu, A.; Aliaga, A.; Kostikov, A.; Do Carmo, S.; Dea, D.; et al. Multimodal Imaging in Rat Model Recapitulates Alzheimer's Disease Biomarkers Abnormalities. J. Neurosci. 2017, 37, 12263-12271. [CrossRef] [PubMed]

117. Govaerts, K.; Lechat, B.; Struys, T.; Kremer, A.; Borghgraef, P.; Van Leuven, F.; Himmelreich, U.; Dresselaers, T. Longitudinal assessment of cerebral perfusion and vascular response to hypoventilation in a bigenic mouse model of Alzheimer's disease with amyloid and tau pathology. NMR Biomed. 2019, 32, e4037. [CrossRef] [PubMed]

118. Lourenço, C.F.; Ledo, A.; Barbosa, R.M.; Laranjinha, J. Neurovascular uncoupling in the triple transgenic model of Alzheimer's disease: Impaired cerebral blood flow response to neuronal-derived nitric oxide signaling. Exp. Neurol. 2017, 291, 36-43. [CrossRef] [PubMed]

119. Li, H.; Guo, Q.; Inoue, T.; Polito, V.A.; Tabuchi, K.; Hammer, R.E.; Pautler, R.G.; Taffet, G.E.; Zheng, H. Vascular and parenchymal amyloid pathology in an Alzheimer disease knock-in mouse model: Interplay with cerebral blood flow. Mol. Neurodegener. 2014, 9, 28. [CrossRef]

120. Maier, F.C.; Wehrl, H.F.; Schmid, A.M.; Mannheim, J.G.; Wiehr, S.; Lerdkrai, C.; Calaminus, C.; Stahlschmidt, A.; Ye, L.; Burnet, M.; et al. Longitudinal PET-MRI reveals $\beta$-amyloid deposition and rCBF dynamics and connects vascular amyloidosis to quantitative loss of perfusion. Nat. Med. 2014, 20, 1485-1492. [CrossRef] [PubMed]

121. Shen, Z.; Lei, J.; Li, X.; Wang, Z.; Bao, X.; Wang, R. Multifaceted assessment of the APP/PS1 mouse model for Alzheimer's disease: Applying MRS, DTI, and ASL. Brain Res. 2018, 1698, 114-120. [CrossRef] [PubMed]

122. Poisnel, G.; Dhilly, M.; Moustié, O.; Delamare, J.; Abbas, A.; Guilloteau, D.; Barré, L. PET imaging with [18F]AV-45 in an APP/PS1-21 murine model of amyloid plaque deposition. Neurobiol. Aging 2012, 33, 2561-2571. [CrossRef] [PubMed]

123. Patrick, D.-M.; Joël, L.; Pier-Luc, T.; Bernard, I.L.; Philippe, P.; Frédéric, L. Whole brain vascular imaging in a mouse model of Alzheimer's disease with two-photon microscopy. J. Biomed. Opt. 2018, 23, 076501. [CrossRef]

124. Hooijmans, C.R.; Graven, C.; Dederen, P.J.; Tanila, H.; van Groen, T.; Kiliaan, A.J. Amyloid beta deposition is related to decreased glucose transporter-1 levels and hippocampal atrophy in brains of aged APP/PS1 mice. Brain Res. 2007, 1181, 93-103. [CrossRef] [PubMed]

125. Faure, A.; Verret, L.; Bozon, B.; El Tannir El Tayara, N.; Ly, M.; Kober, F.; Dhenain, M.; Rampon, C.; Delatour, B. Impaired neurogenesis, neuronal loss, and brain functional deficits in the APPxPS1-Ki mouse model of Alzheimer's disease. Neurobiol. Aging 2011, 32, 407-418. [CrossRef]

126. Munting, L.P.; Derieppe, M.; Suidgeest, E.; Hirschler, L.; van Osch, M.J.; Denis de Senneville, B.; van der Weerd, L. Cerebral blood flow and cerebrovascular reactivity are preserved in a mouse model of cerebral microvascular amyloidosis. eLife 2021, 10, e61279. [CrossRef] [PubMed]

127. Li, M.; Kitamura, A.; Beverley, J.; Koudelka, J.; Duncombe, J.; Platt, B.; Wiegand, U.K.; Carare, R.O.; Kalaria, R.N.; Iliff, J.J.; et al. Pulsation changes link to impaired glymphatic function in a mouse model of vascular cognitive impairment. bioRxiv 2021. [CrossRef]

128. Macdonald, I.R.; DeBay, D.R.; Reid, G.A.; O’Leary, T.P.; Jollymore, C.T.; Mawko, G.; Burrell, S.; Martin, E.; Bowen, C.V.; Brown, R.E.; et al. Early detection of cerebral glucose uptake changes in the 5XFAD mouse. Curr. Alzheimer Res. 2014, 11, 450-460. [CrossRef]

129. Igarashi, H.; Ueki, S.; Kitaura, H.; Kera, T.; Ohno, K.; Ohkubo, M.; Terumitsu-Tsujita, M.; Kakita, A.; Kwee, I.L. Longitudinal GluCEST MRI Changes and Cerebral Blood Flow in 5xFAD Mice. Contrast Media Mol. Imaging 2020, 2020, 8831936. [CrossRef]

130. Nizari, S.; Wells, J.A.; Carare, R.O.; Romero, I.A.; Hawkes, C.A. Loss of cholinergic innervation differentially affects eNOSmediated blood flow, drainage of $\mathrm{A} \beta$ and cerebral amyloid angiopathy in the cortex and hippocampus of adult mice. Acta Neuropathol. Commun. 2021, 9, 12. [CrossRef]

131. Wei, Z.; Xu, J.; Chen, L.; Hirschler, L.; Barbier, E.L.; Li, T.; Wong, P.C.; Lu, H. Brain metabolism in tau and amyloid mouse models of Alzheimer's disease: An MRI study. NMR Biomed. 2021, 34, e4568. [CrossRef]

132. Do, T.M.; Alata, W.; Dodacki, A.; Traversy, M.T.; Chacun, H.; Pradier, L.; Scherrmann, J.M.; Farinotti, R.; Calon, F.; Bourasset, F. Altered cerebral vascular volumes and solute transport at the blood-brain barriers of two transgenic mouse models of Alzheimer's disease. Neuropharmacology 2014, 81, 311-317. [CrossRef]

133. Mueggler, T.; Baumann, D.; Rausch, M.; Staufenbiel, M.; Rudin, M. Age-dependent impairment of somatosensory response in the amyloid precursor protein 23 transgenic mouse model of Alzheimer's disease. J. Neurosci. Off. J. Soc. Neurosci. 2003, 23, 8231-8236. [CrossRef]

134. Krucker, T.; Schuler, A.; Meyer, E.P.; Staufenbiel, M.; Beckmann, N. Magnetic resonance angiography and vascular corrosion casting as tools in biomedical research: Application to transgenic mice modeling Alzheimer's disease. Neurol. Res. 2004, 26, 507-516. [CrossRef] [PubMed]

135. Thal, D.R.; Capetillo-Zarate, E.; Larionov, S.; Staufenbiel, M.; Zurbruegg, S.; Beckmann, N. Capillary cerebral amyloid angiopathy is associated with vessel occlusion and cerebral blood flow disturbances. Neurobiol. Aging 2009, 30, 1936-1948. [CrossRef] 
136. Beckmann, N.; Schuler, A.; Mueggler, T.; Meyer, E.P.; Wiederhold, K.-H.; Staufenbiel, M.; Krucker, T. Age-dependent cerebrovascular abnormalities and blood flow disturbances in APP23 mice modeling Alzheimer's disease. J. Neurosci. 2003, 23, 8453-8459. [CrossRef]

137. Princz-Kranz, F.L.; Mueggler, T.; Knobloch, M.; Nitsch, R.M.; Rudin, M. Vascular response to acetazolamide decreases as a function of age in the arcA beta mouse model of cerebral amyloidosis. Neurobiol. Dis. 2010, 40, 284-292. [CrossRef]

138. Wu, C.C.; Chawla, F.; Games, D.; Rydel, R.E.; Freedman, S.; Schenk, D.; Young, W.G.; Morrison, J.H.; Bloom, F.E. Selective vulnerability of dentate granule cells prior to amyloid deposition in PDAPP mice: Digital morphometric analyses. Proc. Natl. Acad. Sci. USA 2004, 101, 7141-7146. [CrossRef] [PubMed]

139. Moreno, H.; Wu, W.E.; Lee, T.; Brickman, A.; Mayeux, R.; Brown, T.R.; Small, S.A. Imaging the Abeta-related neurotoxicity of Alzheimer disease. Arch. Neurol. 2007, 64, 1467-1477. [CrossRef] [PubMed]

140. Baligand, C.; Barret, O.; Tourais, A.; Pérot, J.B.; Thenadey, D.; Petit, F.; Liot, G.; Gaillard, M.C.; Flament, J.; Dhenain, M.; et al. Zero Echo Time (17)O-MRI Reveals Decreased Cerebral Metabolic Rate of Oxygen Consumption in a Murine Model of Amyloidosis. Metabolites 2021, 11, 263. [CrossRef]

141. Montagne, A.; Nikolakopoulou, A.M.; Huuskonen, M.T.; Sagare, A.P.; Lawson, E.J.; Lazic, D.; Rege, S.V.; Grond, A.; Zuniga, E.; Barnes, S.R.; et al. APOE4 accelerates advanced-stage vascular and neurodegenerative disorder in old Alzheimer's mice via cyclophilin A independently of amyloid- $\beta$. Nat. Aging 2021, 1, 506-520. [CrossRef]

142. Huang, J.; van Zijl, P.C.M.; Han, X.; Dong, C.M.; Cheng, G.W.Y.; Tse, K.H.; Knutsson, L.; Chen, L.; Lai, J.H.C.; Wu, E.X.; et al. Altered d-glucose in brain parenchyma and cerebrospinal fluid of early Alzheimer's disease detected by dynamic glucoseenhanced MRI. Sci. Adv. 2020, 6, eaba3884. [CrossRef] [PubMed]

143. Tolomeo, D.; Micotti, E.; Serra, S.C.; Chappell, M.; Snellman, A.; Forloni, G. Chemical exchange saturation transfer MRI shows low cerebral 2-deoxy-D-glucose uptake in a model of Alzheimer's Disease. Sci. Rep. 2018, 8, 9576. [CrossRef] [PubMed]

144. Chen, L.; Wei, Z.; Chan, K.W.Y.; Cai, S.; Liu, G.; Lu, H.; Wong, P.C.; van Zijl, P.C.M.; Li, T.; Xu, J. Protein aggregation linked to Alzheimer's disease revealed by saturation transfer MRI. NeuroImage 2019, 188, 380-390. [CrossRef] [PubMed]

145. Chen, L.; van Zijl, P.C.M.; Wei, Z.; Lu, H.; Duan, W.; Wong, P.C.; Li, T.; Xu, J. Early detection of Alzheimer's disease using creatine chemical exchange saturation transfer magnetic resonance imaging. NeuroImage 2021, 236, 118071. [CrossRef] [PubMed]

146. Chaney, A.M.; Lopez-Picon, F.R.; Serrière, S.; Wang, R.; Bochicchio, D.; Webb, S.D.; Vandesquille, M.; Harte, M.K.; Georgiadou, C.; Lawrence, C.; et al. Prodromal neuroinflammatory, cholinergic and metabolite dysfunction detected by PET and MRS in the TgF344-AD transgenic rat model of AD: A collaborative multi-modal study. Theranostics 2021, 11, 6644-6667. [CrossRef]

147. Westman, E.; Spenger, C.; Oberg, J.; Reyer, H.; Pahnke, J.; Wahlund, L.O. In vivo 1H-magnetic resonance spectroscopy can detect metabolic changes in APP/PS1 mice after donepezil treatment. BMC Neurosci. 2009, 10, 33. [CrossRef] [PubMed]

148. Kuhla, A.; Rühlmann, C.; Lindner, T.; Polei, S.; Hadlich, S.; Krause, B.J.; Vollmar, B.; Teipel, S.J. APPswe/PS1dE9 mice with cortical amyloid pathology show a reduced NAA/Cr ratio without apparent brain atrophy: A MRS and MRI study. NeuroImage Clin. 2017, 15, 581-586. [CrossRef] [PubMed]

149. Liang, S.; Huang, J.; Liu, W.; Jin, H.; Li, L.; Zhang, X.; Nie, B.; Lin, R.; Tao, J.; Zhao, S.; et al. Magnetic resonance spectroscopy analysis of neurochemical changes in the atrophic hippocampus of APP/PS1 transgenic mice. Behav. Brain Res. 2017, 335, 26-31. [CrossRef]

150. Marjańska, M.; Weigand, S.D.; Preboske, G.; Wengenack, T.M.; Chamberlain, R.; Curran, G.L.; Poduslo, J.F.; Garwood, M.; Kobayashi, D.; Lin, J.C.; et al. Treatment effects in a transgenic mouse model of Alzheimer's disease: A magnetic resonance spectroscopy study after passive immunization. Neuroscience 2014, 259, 94-100. [CrossRef]

151. Marjanska, M.; Curran, G.L.; Wengenack, T.M.; Henry, P.G.; Bliss, R.L.; Poduslo, J.F.; Jack, C.R., Jr.; Ugurbil, K.; Garwood, M. Monitoring disease progression in transgenic mouse models of Alzheimer's disease with proton magnetic resonance spectroscopy. Proc. Natl. Acad. Sci. USA 2005, 102, 11906-11910. [CrossRef]

152. Lee, M.; Lee, H.J.; Jeong, Y.J.; Oh, S.J.; Kang, K.J.; Han, S.J.; Nam, K.R.; Lee, Y.J.; Lee, K.C.; Ryu, Y.H.; et al. Age dependency of mGluR5 availability in 5xFAD mice measured by PET. Neurobiol. Aging 2019, 84, 208-216. [CrossRef] [PubMed]

153. Chiquita, S.; Ribeiro, M.; Castelhano, J.; Oliveira, F.; Sereno, J.; Batista, M.; Abrunhosa, A.; Rodrigues-Neves, A.C.; Carecho, R.; Baptista, F.; et al. A longitudinal multimodal in vivo molecular imaging study of the 3xTg-AD mouse model shows progressive early hippocampal and taurine loss. Hum. Mol. Genet. 2019, 28, 2174-2188. [CrossRef]

154. Oberg, J.; Spenger, C.; Wang, F.H.; Andersson, A.; Westman, E.; Skoglund, P.; Sunnemark, D.; Norinder, U.; Klason, T.; Wahlund, L.O.; et al. Age related changes in brain metabolites observed by 1 H MRS in APP/PS1 mice. Neurobiol. Aging 2008, 29, 1423-1433. [CrossRef]

155. Micotti, E.; Paladini, A.; Balducci, C.; Tolomeo, D.; Frasca, A.; Marizzoni, M.; Filibian, M.; Caroli, A.; Valbusa, G.; Dix, S.; et al. Striatum and entorhinal cortex atrophy in AD mouse models: MRI comprehensive analysis. Neurobiol. Aging 2015, 36, 776-788. [CrossRef]

156. Klohs, J.; Baltes, C.; Princz-Kranz, F.; Ratering, D.; Nitsch, R.M.; Knuesel, I.; Rudin, M. Contrast-enhanced magnetic resonance microangiography reveals remodeling of the cerebral microvasculature in transgenic ArcA $\beta$ mice. J. Neurosci. 2012, 32, 1705-1713. [CrossRef]

157. Yezhuvath, U.S.; Uh, J.; Cheng, Y.; Martin-Cook, K.; Weiner, M.; Diaz-Arrastia, R.; van Osch, M.; Lu, H. Forebrain-dominant deficit in cerebrovascular reactivity in Alzheimer's disease. Neurobiol. Aging 2012, 33, 75-82. [CrossRef] 
158. Richiardi, J.; Monsch, A.U.; Haas, T.; Barkhof, F.; Van de Ville, D.; Radü, E.W.; Kressig, R.W.; Haller, S. Altered cerebrovascular reactivity velocity in mild cognitive impairment and Alzheimer's disease. Neurobiol. Aging 2015, 36, 33-41. [CrossRef] [PubMed]

159. Cantin, S.; Villien, M.; Moreaud, O.; Tropres, I.; Keignart, S.; Chipon, E.; Le Bas, J.F.; Warnking, J.; Krainik, A. Impaired cerebral vasoreactivity to CO2 in Alzheimer's disease using BOLD fMRI. NeuroImage 2011, 58, 579-587. [CrossRef] [PubMed]

160. Iturria-Medina, Y.; Sotero, R.C.; Toussaint, P.J.; Mateos-Pérez, J.M.; Evans, A.C. Early role of vascular dysregulation on late-onset Alzheimer's disease based on multifactorial data-driven analysis. Nat. Commun. 2016, 7, 11934. [CrossRef]

161. Scheffer, S.; Hermkens, D.M.A.; van der Weerd, L.; de Vries, H.E.; Daemen, M.J.A.P. Vascular Hypothesis of Alzheimer Disease. Arterioscler. Thromb. Vasc. Biol. 2021, 41, 1265-1283. [CrossRef]

162. Turner, D.A.; Degan, S.; Hoffmann, U.; Galeffi, F.; Colton, C.A. CVN-AD Alzheimer's mice show premature reduction in neurovascular coupling in response to spreading depression and anoxia compared to aged controls. Alzheimers Dement. 2021, 17, 1109-1120. [CrossRef]

163. Zhang, X.; Yin, X.; Zhang, J.; Li, A.; Gong, H.; Luo, Q.; Zhang, H.; Gao, Z.; Jiang, H. High-resolution mapping of brain vasculature and its impairment in the hippocampus of Alzheimer's disease mice. Natl. Sci. Rev. 2019, 6, 1223-1238. [CrossRef] [PubMed]

164. Telling, N.D.; Everett, J.; Collingwood, J.F.; Dobson, J.; van der Laan, G.; Gallagher, J.J.; Wang, J.; Hitchcock, A.P. Iron Biochemistry is Correlated with Amyloid Plaque Morphology in an Established Mouse Model of Alzheimer's Disease. Cell. Chem. Biol. 2017, 24, 1205-1215.e3. [CrossRef] [PubMed]

165. Beckmann, N.; Doelemeyer, A.; Zurbruegg, S.; Bigot, K.; Theil, D.; Frieauff, W.; Kolly, C.; Moulin, P.; Neddermann, D.; Kreutzer, R.; et al. Longitudinal noninvasive magnetic resonance imaging of brain microhemorrhages in BACE inhibitor-treated APP transgenic mice. Neurobiol. Aging 2016, 45, 50-60. [CrossRef]

166. Maniskas, M.E.; Mack, A.F.; Morales-Scheihing, D.; Finger, C.; Zhu, L.; Paulter, R.; Urayama, A.; McCullough, L.D.; Manwani, B. Sex differences in a murine model of Cerebral Amyloid Angiopathy. Brain Behav. Immun.-Health 2021, 14, 100260. [CrossRef] [PubMed]

167. Klohs, J.; Politano, I.W.; Deistung, A.; Grandjean, J.; Drewek, A.; Dominietto, M.; Keist, R.; Schweser, F.; Reichenbach, J.R.; Nitsch, R.M.; et al. Longitudinal Assessment of Amyloid Pathology in Transgenic ArcA $\beta$ Mice Using Multi-Parametric Magnetic Resonance Imaging. PLoS ONE 2013, 8, e66097. [CrossRef]

168. McIntosh, A.; Mela, V.; Harty, C.; Minogue, A.M.; Costello, D.A.; Kerskens, C.; Lynch, M.A. Iron accumulation in microglia triggers a cascade of events that leads to altered metabolism and compromised function in APP/PS1 mice. Brain Pathol. 2019, 29, 606-621. [CrossRef] [PubMed]

169. Klohs, J.; Deistung, A.; Ielacqua, G.D.; Seuwen, A.; Kindler, D.; Schweser, F.; Vaas, M.; Kipar, A.; Reichenbach, J.R.; Rudin, M. Quantitative assessment of microvasculopathy in $\operatorname{arcA} \beta$ mice with USPIO-enhanced gradient echo MRI. J. Cereb. Blood Flow Metab. 2016, 36, 1614-1624. [CrossRef] [PubMed]

170. Badhwar, A.; Lerch, J.P.; Hamel, E.; Sled, J.G. Impaired structural correlates of memory in Alzheimer's disease mice. NeuroImage Clin. 2013, 3, 290-300. [CrossRef] [PubMed]

171. Maheswaran, S.; Barjat, H.; Rueckert, D.; Bate, S.T.; Howlett, D.R.; Tilling, L.; Smart, S.C.; Pohlmann, A.; Richardson, J.C.; Hartkens, T.; et al. Longitudinal regional brain volume changes quantified in normal aging and Alzheimer's APP x PS1 mice using MRI. Brain Res. 2009, 1270, 19-32. [CrossRef] [PubMed]

172. Delatour, B.; Guégan, M.; Volk, A.; Dhenain, M. In vivo MRI and histological evaluation of brain atrophy in APP/PS1 transgenic mice. Neurobiol. Aging 2006, 27, 835-847. [CrossRef]

173. Lau, J.C.; Lerch, J.P.; Sled, J.G.; Henkelman, R.M.; Evans, A.C.; Bedell, B.J. Longitudinal neuroanatomical changes determined by deformation-based morphometry in a mouse model of Alzheimer's disease. NeuroImage 2008, 42, 19-27. [CrossRef]

174. Kang, M.S.; Aliaga, A.A.; Shin, M.; Mathotaarachchi, S.; Benedet, A.L.; Pascoal, T.A.; Therriault, J.; Chamoun, M.; Savard, M.; Devenyi, G.A.; et al. Amyloid-beta modulates the association between neurofilament light chain and brain atrophy in Alzheimer's disease. Mol. Psychiatry 2020, 1-13. [CrossRef]

175. Redwine, J.M.; Kosofsky, B.; Jacobs, R.E.; Games, D.; Reilly, J.F.; Morrison, J.H.; Young, W.G.; Bloom, F.E. Dentate gyrus volume is reduced before onset of plaque formation in PDAPP mice: A magnetic resonance microscopy and stereologic analysis. Proc. Natl. Acad. Sci. USA 2003, 100, 1381-1386. [CrossRef] [PubMed]

176. Weiss, C.; Venkatasubramanian, P.; Aguado, A.; Power, J.; Tom, B.; Li, L.; Chen, K.; Disterhoft, J.; Wyrwicz, A. Impaired Eyeblink Conditioning and Decreased Hippocampal Volume in PDAPP V717F Mice. Neurobiol. Dis. 2003, 11, 425-433. [CrossRef]

177. Van Broeck, B.; Vanhoutte, G.; Pirici, D.; Van Dam, D.; Wils, H.; Cuijt, I.; Vennekens, K.1.; Zabielski, M.; Michalik, A.; Theuns, J.; et al. Intraneuronal amyloid $\beta$ and reduced brain volume in a novel APP T714I mouse model for Alzheimer's disease. Neurobiol. Aging 2008, 29, 241-252. [CrossRef] [PubMed]

178. Rollins, C.P.E.; Gallino, D.; Kong, V.; Ayranci, G.; Devenyi, G.A.; Germann, J.; Chakravarty, M.M. Contributions of a high-fat diet to Alzheimer's disease-related decline: A longitudinal behavioural and structural neuroimaging study in mouse models. NeuroImage. Clin. 2019, 21, 101606. [CrossRef]

179. Kong, V.; Devenyi, G.A.; Gallino, D.; Ayranci, G.; Germann, J.; Rollins, C.; Chakravarty, M.M. Early-in-life neuroanatomical and behavioural trajectories in a triple transgenic model of Alzheimer's disease. Brain Struct. Funct. 2018, 223, 3365-3382. [CrossRef] [PubMed]

180. Breyhan, H.; Wirths, O.; Duan, K.; Marcello, A.; Rettig, J.; Bayer, T.A. APP/PS1KI bigenic mice develop early synaptic deficits and hippocampus atrophy. Acta Neuropathol. 2009, 117, 677-685. [CrossRef] [PubMed] 
181. Badea, A.; Gewalt, S.; Avants, B.B.; Cook, J.J.; Johnson, G.A. Quantitative mouse brain phenotyping based on single and multispectral MR protocols. NeuroImage 2012, 63, 1633-1645. [CrossRef]

182. Praet, J.; Manyakov, N.V.; Muchene, L.; Mai, Z.; Terzopoulos, V.; de Backer, S.; Torremans, A.; Guns, P.-J.; Van De Casteele, T.; Bottelbergs, A.; et al. Diffusion kurtosis imaging allows the early detection and longitudinal follow-up of amyloid- $\beta$-induced pathology. Alzheimers Res. Ther. 2018, 10,1. [CrossRef] [PubMed]

183. Falangola, M.F.; Nie, X.; Ward, R.; Dhiman, S.; Voltin, J.; Nietert, P.J.; Jensen, J.H. Diffusion MRI detects basal forebrain cholinergic abnormalities in the 3xTg-AD mouse model of Alzheimer's disease. Magn. Reson. Imaging 2021, 83, 1-13. [CrossRef]

184. Whittaker, H.T.; Zhu, S.; Di Curzio, D.L.; Buist, R.; Li, X.-M.; Noy, S.; Wiseman, F.K.; Thiessen, J.D.; Martin, M. T1, diffusion tensor, and quantitative magnetization transfer imaging of the hippocampus in an Alzheimer's disease mouse model. Magn. Reson. Imaging 2018, 50, 26-37. [CrossRef] [PubMed]

185. Daianu, M.; Jacobs, R.E.; Weitz, T.M.; Town, T.C.; Thompson, P.M. Multi-Shell Hybrid Diffusion Imaging (HYDI) at 7 Tesla in TgF344-AD Transgenic Alzheimer Rats. PLoS ONE 2015, 10, e0145205. [CrossRef] [PubMed]

186. Sun, S.W.; Song, S.K.; Harms, M.P.; Lin, S.J.; Holtzman, D.M.; Merchant, K.M.; Kotyk, J.J. Detection of age-dependent brain injury in a mouse model of brain amyloidosis associated with Alzheimer's disease using magnetic resonance diffusion tensor imaging. Exp. Neurol. 2005, 191, 77-85. [CrossRef]

187. Song, S.K.; Yoshino, J.; Le, T.Q.; Lin, S.J.; Sun, S.W.; Cross, A.H.; Armstrong, R.C. Demyelination increases radial diffusivity in corpus callosum of mouse brain. NeuroImage 2005, 26, 132-140. [CrossRef]

188. Müller, H.P.; Kassubek, J.; Vernikouskaya, I.; Ludolph, A.C.; Stiller, D.; Rasche, V. Diffusion tensor magnetic resonance imaging of the brain in APP transgenic mice: A cohort study. PLoS ONE 2013, 8, e67630. [CrossRef]

189. Song, S.K.; Kim, J.H.; Lin, S.J.; Brendza, R.P.; Holtzman, D.M. Diffusion tensor imaging detects age-dependent white matter changes in a transgenic mouse model with amyloid deposition. Neurobiol. Dis. 2004, 15, 640-647. [CrossRef]

190. Shepherd, T.M.; Ozarslan, E.; King, M.A.; Mareci, T.H.; Blackband, S.J. Structural insights from high-resolution diffusion tensor imaging and tractography of the isolated rat hippocampus. NeuroImage 2006, 32, 1499-1509. [CrossRef]

191. Zerbi, V.; Kleinnijenhuis, M.; Fang, X.; Jansen, D.; Veltien, A.; Van Asten, J.; Timmer, N.; Dederen, P.J.; Kiliaan, A.J.; Heerschap, A. Gray and white matter degeneration revealed by diffusion in an Alzheimer mouse model. Neurobiol. Aging 2013, 34, 1440-1450. [CrossRef]

192. Zhou, C.; Sun, X.; Hu, Y.; Song, J.; Dong, S.; Kong, D.; Wang, Y.; Hua, X.; Han, J.; Zhou, Y.; et al. Genomic deletion of TLR2 induces aggravated white matter damage and deteriorated neurobehavioral functions in mouse models of Alzheimer's disease. Aging 2019, 11, 7257-7273. [CrossRef]

193. Shu, X.; Qin, Y.Y.; Zhang, S.; Jiang, J.J.; Zhang, Y.; Zhao, L.Y.; Shan, D.; Zhu, W.Z. Voxel-based diffusion tensor imaging of an APP/PS1 mouse model of Alzheimer's disease. Mol. Neurobiol. 2013, 48, 78-83. [CrossRef] [PubMed]

194. Qin, Y.Y.; Li, M.W.; Zhang, S.; Zhang, Y.; Zhao, L.Y.; Lei, H.; Oishi, K.; Zhu, W.Z. In vivo quantitative whole-brain diffusion tensor imaging analysis of APP/PS1 transgenic mice using voxel-based and atlas-based methods. Neuroradiology 2013, 55, 1027-1038. [CrossRef]

195. Mueggler, T.; Meyer-Luehmann, M.; Rausch, M.; Staufenbiel, M.; Jucker, M.; Rudin, M. Restricted diffusion in the brain of transgenic mice with cerebral amyloidosis. Eur. J. Neurosci. 2004, 20, 811-817. [CrossRef]

196. Snow, W.M.; Dale, R.; O'Brien-Moran, Z.; Buist, R.; Peirson, D.; Martin, M.; Albensi, B.C. In Vivo Detection of Gray Matter Neuropathology in the 3xTg Mouse Model of Alzheimer's Disease with Diffusion Tensor Imaging. J. Alzheimers Dis. 2017, 58, 841-853. [CrossRef] [PubMed]

197. Bittner, T.; Fuhrmann, M.; Burgold, S.; Ochs, S.M.; Hoffmann, N.; Mitteregger, G.; Kretzschmar, H.; LaFerla, F.M.; Herms, J. Multiple Events Lead to Dendritic Spine Loss in Triple Transgenic Alzheimer's Disease Mice. PLoS ONE 2010, 5 , e15477. [CrossRef]

198. Kastyak-Ibrahim, M.Z.; Di Curzio, D.L.; Buist, R.; Herrera, S.L.; Albensi, B.C.; Del Bigio, M.R.; Martin, M. Neurofibrillary tangles and plaques are not accompanied by white matter pathology in aged triple transgenic-Alzheimer disease mice. Magn. Reson. Imaging 2013, 31, 1515-1521. [CrossRef]

199. Falangola, M.F.; Nie, X.; Ward, R.; McKinnon, E.T.; Dhiman, S.; Nietert, P.J.; Helpern, J.A.; Jensen, J.H. Diffusion MRI detects early brain microstructure abnormalities in 2-month-old $3 \times$ Tg-AD mice. NMR Biomed. 2020, 33, e4346. [CrossRef] [PubMed]

200. Ielacqua, G.D.; Schlegel, F.; Füchtemeier, M.; Xandry, J.; Rudin, M.; Klohs, J. Magnetic Resonance Q Mapping Reveals a Decrease in Microvessel Density in the arcA $\beta$ Mouse Model of Cerebral Amyloidosis. Front. Aging Neurosci. 2015, 7, 241. [CrossRef]

201. Montagne, A.; Gauberti, M.; Macrez, R.; Jullienne, A.; Briens, A.; Raynaud, J.S.; Louin, G.; Buisson, A.; Haelewyn, B.; Docagne, F.; et al. Ultra-sensitive molecular MRI of cerebrovascular cell activation enables early detection of chronic central nervous system disorders. NeuroImage 2012, 63, 760-770. [CrossRef]

202. Leaston, J.; Ferris, C.F.; Kulkarni, P.; Chandramohan, D.; van de Ven, A.L.; Qiao, J.; Timms, L.; Sepulcre, J.; El Fakhri, G.; Ma, C.; et al. Neurovascular imaging with QUTE-CE MRI in APOE4 rats reveals early vascular abnormalities. PLoS ONE 2021, 16, e0256749. [CrossRef]

203. Chang, S.K.; Kim, J.; Lee, D.; Yoo, C.H.; Jin, S.; Rhee, H.Y.; Ryu, C.W.; Lee, J.K.; Cho, H.; Jahng, G.H. Mapping of microvascular architecture in the brain of an Alzheimer's disease mouse model using MRI. NMR Biomed. 2021, 34, e4481. [CrossRef] [PubMed]

204. El Tayara Nel, T.; Delatour, B.; Volk, A.; Dhenain, M. Detection of vascular alterations by in vivo magnetic resonance angiography and histology in APP/PS1 mouse model of Alzheimer's disease. Magma 2010, 23, 53-64. [CrossRef] [PubMed] 
205. Kara, F.; van Dongen, E.S.; Schliebs, R.; van Buchem, M.A.; de Groot, H.J.M.; Alia, A. Monitoring blood flow alterations in the Tg2576 mouse model of Alzheimer's disease by in vivo magnetic resonance angiography at 17.6T. NeuroImage 2012, 60, 958-966. [CrossRef] [PubMed]

206. Majumdar, S.; Klatt, D. Longitudinal study of sub-regional cerebral viscoelastic properties of 5XFAD Alzheimer's disease mice using multifrequency MR elastography. Magn. Reson. Med. 2021, 86, 405-414. [CrossRef] [PubMed]

207. Murphy, M.C.; Curran, G.L.; Glaser, K.J.; Rossman, P.J.; Huston, J., III; Poduslo, J.F.; Jack, C.R., Jr.; Felmlee, J.P.; Ehman, R.L. Magnetic resonance elastography of the brain in a mouse model of Alzheimer's disease: Initial results. Magn. Reson. Imaging 2012, 30, 535-539. [CrossRef]

208. Munder, T.; Pfeffer, A.; Schreyer, S.; Guo, J.; Braun, J.; Sack, I.; Steiner, B.; Klein, C. MR elastography detection of early viscoelastic response of the murine hippocampus to amyloid $\beta$ accumulation and neuronal cell loss due to Alzheimer's disease. J. Magn. Reson. Imaging 2018, 47, 105-114. [CrossRef]

209. Hilal, S.; Xu, X.; Ikram, M.K.; Vrooman, H.; Venketasubramanian, N.; Chen, C. Intracranial stenosis in cognitive impairment and dementia. J. Cereb. Blood Flow Metab. 2017, 37, 2262-2269. [CrossRef]

210. Roher, A.E.; Esh, C.; Rahman, A.; Kokjohn, T.A.; Beach, T.G. Atherosclerosis of cerebral arteries in Alzheimer disease. Stroke 2004, 35, 2623-2627. [CrossRef]

211. Badea, A.; Johnson, G.A.; Jankowsky, J.L. Remote sites of structural atrophy predict later amyloid formation in a mouse model of Alzheimer's disease. NeuroImage 2010, 50, 416-427. [CrossRef]

212. Nasrabady, S.E.; Rizvi, B.; Goldman, J.E.; Brickman, A.M. White matter changes in Alzheimer's disease: A focus on myelin and oligodendrocytes. Acta Neuropathol. Commun. 2018, 6, 22. [CrossRef] [PubMed]

213. Araque Caballero, M.Á.; Suárez-Calvet, M.; Duering, M.; Franzmeier, N.; Benzinger, T.; Fagan, A.M.; Bateman, R.J.; Jack, C.R.; Levin, J.; Dichgans, M.; et al. White matter diffusion alterations precede symptom onset in autosomal dominant Alzheimer's disease. Brain 2018, 141, 3065-3080. [CrossRef] [PubMed]

214. Chen, J.-F.; Liu, K.; Hu, B.; Li, R.-R.; Xin, W.; Chen, H.; Wang, F.; Chen, L.; Li, R.-X.; Ren, S.-Y.; et al. Enhancing myelin renewal reverses cognitive dysfunction in a murine model of Alzheimer's disease. Neuron 2021, 109, 2292-2307.e2295. [CrossRef] [PubMed]

215. Depp, C.; Sun, T.; Sasmita, A.O.; Spieth, L.; Berghoff, S.; Steixner-Kumar, A.; Subramanian, S.; Möbius, W.; Göbbels, S.; Saher, G.; et al. Ageing-associated myelin dysfunction drives amyloid deposition in mouse models of Alzheimer's disease. bioRxiv 2021. [CrossRef]

216. Nie, X.; Falangola, M.F.; Ward, R.; McKinnon, E.T.; Helpern, J.A.; Nietert, P.J.; Jensen, J.H. Diffusion MRI detects longitudinal white matter changes in the 3xTg-AD mouse model of Alzheimer's disease. Magn. Reson. Imaging 2019, 57, 235-242. [CrossRef]

217. Weishaupt, N.; Liu, Q.; Shin, S.; Singh, R.; Agca, Y.; Agca, C.; Hachinski, V.; Whitehead, S.N. APP21 transgenic rats develop age-dependent cognitive impairment and microglia accumulation within white matter tracts. J. Neuroinflamm. 2018, 15, 241. [CrossRef]

218. Hara, Y.; Motoi, Y.; Hikishima, K.; Mizuma, H.; Onoe, H.; Matsumoto, S.E.; Elahi, M.; Okano, H.; Aoki, S.; Hattori, N. Involvement of the Septo-Hippocampal Cholinergic Pathway in Association with Septal Acetylcholinesterase Upregulation in a Mouse Model of Tauopathy. Curr. Alzheimer Res. 2017, 14, 94-103. [CrossRef]

219. Nishioka, C.; Liang, H.-F.; Barsamian, B.; Sun, S.-W. Amyloid-beta induced retrograde axonal degeneration in a mouse tauopathy model. NeuroImage 2019, 189, 180-191. [CrossRef]

220. Zahs, K.R.; Ashe, K.H. 'Too much good news'-Are Alzheimer mouse models trying to tell us how to prevent, not cure, Alzheimer's disease? Trends Neurosci. 2010, 33, 381-389. [CrossRef]

221. Ashe, K.H.; Zahs, K.R. Probing the biology of Alzheimer's disease in mice. Neuron 2010, 66, 631-645. [CrossRef]

222. Joel, Z.; Izquierdo, P.; Salih, D.A.; Richardson, J.C.; Cummings, D.M.; Edwards, F.A. Improving Mouse Models for Dementia. Are All the Effects in Tau Mouse Models Due to Overexpression? Cold Spring Harb. Symp. Quant. Biol. 2018, 83, 151-161. [CrossRef] [PubMed]

223. Denny, P.; Justice, M.J. Mouse as the measure of man? Trends Genet. 2000, 16, 283-287. [CrossRef]

224. Neuner, S.M.; Heuer, S.E.; Huentelman, M.J.; O'Connell, K.M.S.; Kaczorowski, C.C. Harnessing Genetic Complexity to Enhance Translatability of Alzheimer's Disease Mouse Models: A Path toward Precision Medicine. Neuron 2019, 101, 399-411.e395. [CrossRef] [PubMed]

225. Ren, W.; Ni, R.; Vaas, M.; Jan Klohs, J.; Ripoll, J.; Wolf, M.; Rudin, M. Non-invasive visualization of amyloid-beta deposits in Alzheimer amyloidosis mice using magnetic resonance imaging and fluorescence molecular tomography. bioRxiv 2021. [CrossRef]

226. Ni, R.; Villois, A.; Dean-Ben, X.L.; Chen, Z.; Vaas, M.; Stavrakis, S.; Shi, G.; deMello, A.; Ran, C.; Razansky, D.; et al. In-vitro and in-vivo characterization of CRANAD-2 for multi-spectral optoacoustic tomography and fluorescence imaging of amyloid-beta deposits in Alzheimer mice. Photoacoustics 2021, 23, 100285. [CrossRef] [PubMed]

227. Calvo-Rodriguez, M.; Hou, S.S.; Snyder, A.C.; Dujardin, S.; Shirani, H.; Nilsson, K.P.R.; Bacskai, B.J. In vivo detection of tau fibrils and amyloid $\beta$ aggregates with luminescent conjugated oligothiophenes and multiphoton microscopy. Acta Neuropathol. Commun. 2019, 7, 171. [CrossRef] [PubMed]

228. Ni, R.; Chen, Z.; Shi, G.; Villois, A.; Zhou, Q.; Arosio, P.; Nitsch, R.M.; Nilsson, K.P.R.; Klohs, J.; Razansky, D. Transcranial in vivo detection of amyloid-beta at single plaque resolution with large-field multifocal illumination fluorescence microscopy. bioRxiv 2020. [CrossRef] 
229. Ni, R.; Dean-Ben, X.L.; Kirschenbaum, D.; Rudin, M.; Chen, Z.; Crimi, A.; Voigt, F.F.; Nilsson, K.P.R.; Helmchen, F.; Nitsch, R. Whole brain optoacoustic tomography reveals strain-specific regional beta-amyloid densities in Alzheimer's disease amyloidosis models. bioRxiv 2020. [CrossRef]

230. Razansky, D.; Klohs, J.; Ni, R. Multi-scale optoacoustic molecular imaging of brain diseases. Eur. J. Nucl. Med. Mol. Imaging 2021, 48, 4152-4170. [CrossRef]

231. Rodriguez-Vieitez, E.; Ni, R.; Gulyas, B.; Toth, M.; Haggkvist, J.; Halldin, C.; Voytenko, L.; Marutle, A.; Nordberg, A. Astrocytosis precedes amyloid plaque deposition in Alzheimer APPswe transgenic mouse brain: A correlative positron emission tomography and in vitro imaging study. Eur. J. Nucl. Med. Mol. Imaging 2015, 42, 1119-1132. [CrossRef]

232. Ni, R. Positron Emission Tomography in Animal Models of Alzheimer's Disease Amyloidosis: Translational Implications. Pharmaceuticals 2021, 14, 1179. [CrossRef]

233. Ni, R.; Gillberg, P.-G.; Bogdanovic, N.; Viitanen, M.; Myllykangas, L.; Nennesmo, I.; Långström, B.; Nordberg, A. Amyloid tracers binding sites in autosomal dominant and sporadic Alzheimer's disease. Alzheimers Dement. 2017, 13, 419-430. [CrossRef] [PubMed]

234. Logothetis, N.K.; Pauls, J.; Augath, M.; Trinath, T.; Oeltermann, A. Neurophysiological investigation of the basis of the fMRI signal. Nature 2001, 412, 150-157. [CrossRef] [PubMed]

235. Polimeni, J.R.; Lewis, L.D. Imaging faster neural dynamics with fast fMRI: A need for updated models of the hemodynamic response. Prog Neurobiol. 2021, 102174. [CrossRef] [PubMed]

236. Deán-Ben, X.L.; Robin, J.; Ni, R.; Razansky, D. Noninvasive three-dimensional optoacoustic localization microangiography of deep tissues. arXiv 2020, arXiv:2007.00372.

237. Senatorov, V.V., Jr.; Friedman, A.R.; Milikovsky, D.Z.; Ofer, J.; Saar-Ashkenazy, R.; Charbash, A.; Jahan, N.; Chin, G.; Mihaly, E.; Lin, J.M.; et al. Blood-brain barrier dysfunction in aging induces hyperactivation of TGF $\beta$ signaling and chronic yet reversible neural dysfunction. Sci. Transl. Med. 2019, 11, eaaw8283. [CrossRef] [PubMed]

238. Sweeney, M.D.; Sagare, A.P.; Zlokovic, B.V. Blood-brain barrier breakdown in Alzheimer disease and other neurodegenerative disorders. Nat. Rev. Neurol. 2018, 14, 133-150. [CrossRef]

239. Nation, D.A.; Sweeney, M.D.; Montagne, A.; Sagare, A.P.; D’Orazio, L.M.; Pachicano, M.; Sepehrband, F.; Nelson, A.R.; Buennagel, D.P.; Harrington, M.G.; et al. Blo.ood-brain barrier breakdown is an early biomarker of human cognitive dysfunction. Nat. Med. 2019, 25, 270-276. [CrossRef]

240. Montagne, A.; Nation, D.A.; Sagare, A.P.; Barisano, G.; Sweeney, M.D.; Chakhoyan, A.; Pachicano, M.; Joe, E.; Nelson, A.R.; D'Orazio, L.M.; et al. APOE4 leads to blood-brain barrier dysfunction predicting cognitive decline. Nature 2020, 581, 71-76. [CrossRef]

241. van de Haar, H.J.; Burgmans, S.; Jansen, J.F.; van Osch, M.J.; van Buchem, M.A.; Muller, M.; Hofman, P.A.; Verhey, F.R.; Backes, W.H. Blood-Brain Barrier Leakage in Patients with Early Alzheimer Disease. Radiology 2016, 281, 527-535. [CrossRef]

242. Ishii, M.; Iadecola, C. Risk factor for Alzheimer's disease breaks the blood-brain barrier. Nature 2020, 581, 31-32. [CrossRef] [PubMed]

243. Bien-Ly, N.; Boswell, C.A.; Jeet, S.; Beach, T.G.; Hoyte, K.; Luk, W.; Shihadeh, V.; Ulufatu, S.; Foreman, O.; Lu, Y.; et al. Lack of Widespread BBB Disruption in Alzheimer's Disease Models: Focus on Therapeutic Antibodies. Neuron 2015, 88, $289-297$. [CrossRef]

244. Montagne, A.; Barnes, S.R.; Sweeney, M.D.; Halliday, M.R.; Sagare, A.P.; Zhao, Z.; Toga, A.W.; Jacobs, R.E.; Liu, C.Y.; Amezcua, L.; et al. Blood-brain barrier breakdown in the aging human hippocampus. Neuron 2015, 85, 296-302. [CrossRef] [PubMed]

245. Dickie, B.R.; Vandesquille, M.; Ulloa, J.; Boutin, H.; Parkes, L.M.; Parker, G.J.M. Water-exchange MRI detects subtle blood-brain barrier breakdown in Alzheimer's disease rats. NeuroImage 2019, 184, 349-358. [CrossRef] [PubMed]

246. Dickie, B.R.; Boutin, H.; Parker, G.J.M.; Parkes, L.M. Alzheimer's disease pathology is associated with earlier alterations to blood-brain barrier water permeability compared with healthy ageing in TgF344-AD rats. NMR Biomed. 2021, 34 , e4510. [CrossRef]

247. Iliff, J.J.; Wang, M.; Liao, Y.; Plogg, B.A.; Peng, W.; Gundersen, G.A.; Benveniste, H.; Vates, G.E.; Deane, R.; Goldman, S.A.; et al. A paravascular pathway facilitates CSF flow through the brain parenchyma and the clearance of interstitial solutes, including amyloid beta. Sci. Transl. Med. 2012, 4, 147ra111. [CrossRef] [PubMed]

248. Nedergaard, M.; Goldman, S.A. Glymphatic failure as a final common pathway to dementia. Science 2020, 370, 50-56. [CrossRef] [PubMed]

249. Xie, L.; Kang, H.; Xu, Q.; Chen, M.J.; Liao, Y.; Thiyagarajan, M.; O’Donnell, J.; Christensen, D.J.; Nicholson, C.; Iliff, J.J.; et al. Sleep drives metabolite clearance from the adult brain. Science 2013, 342, 373-377. [CrossRef]

250. Hawkes, C.A.; Härtig, W.; Kacza, J.; Schliebs, R.; Weller, R.O.; Nicoll, J.A.; Carare, R.O. Perivascular drainage of solutes is impaired in the ageing mouse brain and in the presence of cerebral amyloid angiopathy. Acta Neuropathol. 2011, 121, 431-443. [CrossRef]

251. Da Mesquita, S.; Louveau, A.; Vaccari, A.; Smirnov, I.; Cornelison, R.C.; Kingsmore, K.M.; Contarino, C.; Onengut-Gumuscu, S.; Farber, E.; Raper, D.; et al. Functional aspects of meningeal lymphatics in ageing and Alzheimer's disease. Nature 2018, 560, 185-191. [CrossRef]

252. Da Mesquita, S.; Papadopoulos, Z.; Dykstra, T.; Brase, L.; Farias, F.G.; Wall, M.; Jiang, H.; Kodira, C.D.; de Lima, K.A.; Herz, J.; et al. Meningeal lymphatics affect microglia responses and anti-A $\beta$ immunotherapy. Nature 2021, 593, 255-260. [CrossRef] 
253. Ringstad, G.; Vatnehol, S.A.S.; Eide, P.K. Glymphatic MRI in idiopathic normal pressure hydrocephalus. Brain 2017, 140, 2691-2705. [CrossRef] [PubMed]

254. Watts, R.; Steinklein, J.M.; Waldman, L.; Zhou, X.; Filippi, C.G. Measuring Glymphatic Flow in Man Using Quantitative Contrast-Enhanced MRI. AJNR Am. J. Neuroradiol. 2019, 40, 648-651. [CrossRef]

255. Harrison, I.F.; Ismail, O.; Machhada, A.; Colgan, N.; Ohene, Y.; Nahavandi, P.; Ahmed, Z.; Fisher, A.; Meftah, S.; Murray, T.K.; et al. Impaired glymphatic function and clearance of tau in an Alzheimer's disease model. Brain 2020, 143, 2576-2593. [CrossRef]

256. Lee, H.; Mortensen, K.; Sanggaard, S.; Koch, P.; Brunner, H.; Quistorff, B.; Nedergaard, M.; Benveniste, H. Quantitative Gd-DOTA uptake from cerebrospinal fluid into rat brain using 3D VFA-SPGR at 9.4T. Magn. Reson. Med. 2018, 79, 1568-1578. [CrossRef]

257. Iliff, J.J.; Lee, H.; Yu, M.; Feng, T.; Logan, J.; Nedergaard, M.; Benveniste, H. Brain-wide pathway for waste clearance captured by contrast-enhanced MRI. J. Clin. Investig. 2013, 123, 1299-1309. [CrossRef]

258. Lee, H.; Xie, L.; Yu, M.; Kang, H.; Feng, T.; Deane, R.; Logan, J.; Nedergaard, M.; Benveniste, H. The Effect of Body Posture on Brain Glymphatic Transport. J. Neurosci. 2015, 35, 11034-11044. [CrossRef] [PubMed]

259. Harrison, I.F.; Siow, B.; Akilo, A.B.; Evans, P.G.; Ismail, O.; Ohene, Y.; Nahavandi, P.; Thomas, D.L.; Lythgoe, M.F.; Wells, J.A. Non-invasive imaging of CSF-mediated brain clearance pathways via assessment of perivascular fluid movement with diffusion tensor MRI. eLife 2018, 7, e34028. [CrossRef] [PubMed]

260. Taoka, T.; Masutani, Y.; Kawai, H.; Nakane, T.; Matsuoka, K.; Yasuno, F.; Kishimoto, T.; Naganawa, S. Evaluation of glymphatic system activity with the diffusion MR technique: Diffusion tensor image analysis along the perivascular space (DTI-ALPS) in Alzheimer's disease cases. Jpn. J. Radiol. 2017, 35, 172-178. [CrossRef] [PubMed]

261. Li, A.M.; Xu, J. Interstitial and cerebrospinal fluid exchanging process revealed by phase alternate labeling with null recovery MRI. bioRxiv 2021. [CrossRef]

262. Ahmed, T.; He, C.; Abbasi, A.; Li, L.; Foltz, W.; Cai, P.; Knock, E.; Fraser, P.; Rauth, A.; Henderson, J.; et al. Multifunctional bioreactive-nanoconstructs for sensitive and accurate MRI of cerebrospinal fluid pathology and intervention of Alzheimer's disease. Nano Today 2020, 35, 100965. [CrossRef] 